\begin{tabular}{|c|l|}
\hline Title & $\begin{array}{l}\text { Iron and humic-type fluorescent dissolved organic matter in the Chukchi Sea and Canada Basin of the western A rctic } \\
\text { Ocean }\end{array}$ \\
\hline Author(s) & Nakayama, Y uta; Fujita, Satoshi; Kuma, Kenshi; Shimada, Koji \\
\hline Citation & $\begin{array}{l}\text { Journal of Geophysical Research, Oceans, 116, C07031 } \\
\text { https://doi.org/_0.1029/2010JCO06779 }\end{array}$ \\
\hline Issue Date & 2011-07-29 \\
\hline Doc URL & http://hdl.handle.net/2115/48148 \\
\hline Rights & Copyright 2011 by the A merican Geophysical Union. \\
\hline Type & article \\
\hline File Information & JGRO116_C07031.pdf \\
\hline
\end{tabular}

Instructions for use 


\title{
Iron and humic-type fluorescent dissolved organic matter in the Chukchi Sea and Canada Basin of the western Arctic Ocean
}

\author{
Yuta Nakayama, ${ }^{1}$ Satoshi Fujita, ${ }^{1}$ Kenshi Kuma, ${ }^{2}$ and Koji Shimada ${ }^{3}$ \\ Received 29 October 2010; revised 22 February 2011; accepted 20 April 2011; published 29 July 2011.
}

[1] The concentrations of dissolved Fe ([D-Fe]), total dissolvable Fe ([T-Fe]), humic-type fluorescence intensity (humic F intensity) as humic-type fluorescent dissolved organic matter, and nutrients were vertically determined in the shelf, slope, and basin regions (Chukchi Sea and Canada Basin) of the western Arctic Ocean during 1-27 September 2008. In all stations, the remarkably high [D-Fe] and humic $\mathrm{F}$ intensity were found at depths between 25 and $200 \mathrm{~m}$ with the subsurface maxima of [D-Fe] (1.0-3.2 nM) and humic F intensity (4-5 quinine sulfate units) in the upper halocline layer (upper HL), being associated with a prominent nutrient maximum. The high [D-Fe] and humic $\mathrm{F}$ intensity within the upper HL are probably attributed to the Fe(III) complexation with natural organic ligands, such as marine dissolved humic substances, resulting from main processes of the brine rejection during sea ice formation and interactions with sediments on the shelves. However, subsurface maxima (10-50 nM) of [T-Fe] were found in the lower halocline layer, beneath the upper HL, of all slope and basin regions and are mainly attributed to the resuspension of sedimentary particles in the shelf region. The finding of subsurface iron maxima in the halocline water of all regions may be the first confirmation for the lateral iron transport into the halocline layer from the shelves to the Arctic Basin.

Citation: Nakayama, Y., S. Fujita, K. Kuma, and K. Shimada (2011), Iron and humic-type fluorescent dissolved organic matter in the Chukchi Sea and Canada Basin of the western Arctic Ocean, J. Geophys. Res., 116, C07031, doi:10.1029/2010JC006779.

\section{Introduction}

[2] The Arctic Ocean is characterized by its large continental shelf, which represents approximately one third of its surface area. During sea ice formation in winter, cold dense water cascading over the continental shelf around the Arctic Ocean could be an important transport for chemical species, such as sea salts, dissolved organic matter (DOM) and nutrient, from the shelf to the Arctic Basin [Guéguen et al., 2007; Nishino et al., 2008]. An important feature of the upper surface water column in the Arctic Ocean is the dominance of a strong cold halocline that separates the surface water from the underlying Atlantic-origin waters. In the Canada Basin, Pacific-origin water entering through the Bering Strait can be highly modified on the shelves by runoff and sea ice formation. The upper halocline layer (upper HL) is associated with prominent nutrient and DOM maxima [Jones and Anderson, 1986; Wang et al., 2006; Guéguen et al., 2007] due to sea ice formation [Aagaard et al., 1981; Melling and Lewis, 1982] and interactions with bottom sediments on the shelves [Moore et al., 1983]. The lower halocline layer (lower HL) is found beneath the upper HL and

\footnotetext{
${ }^{1}$ Graduate School of Environmental Science, Hokkaido University, Sapporo, Hokkaido, Japan.

${ }^{2}$ Faculty of Fisheries Sciences, Hokkaido University, Hakodate, Japan.

${ }^{3}$ Department of Ocean Sciences, Tokyo University of Marine Science and Technology, Tokyo, Japan.

Copyright 2011 by the American Geophysical Union. 0148-0227/11/2010JC006779
}

mainly originates from the Atlantic. Mixtures containing Atlantic water are only found below the nutrient maximum in the Canada Basin [Yamamoto-Kawai et al., 2008]. The Atlantic water extends from about $250-850 \mathrm{~m}$ and the Canadian Basin Deep Water (CBDW) is found at depths greater than $850-1000 \mathrm{~m}$. Despite the great interest in the behavior of iron in open oceans, our understanding of the biogeochemical and physical mechanisms that regulate iron and other trace metals is still limited in subarctic and arctic marginal seas, such as the Bering Sea, the Okhotsk Sea and the Arctic Ocean.

[3] In general, dissolved Fe ([D-Fe]) in remote oceanic regions are characterized by surface depletion and a gradual increase with depth below the surface water and release from microbial decomposition of sinking organic matter in deep water [Johnson et al., 1997]. [D-Fe] distributions in the deep water column are mainly controlled by the production of dissolved Fe from particulate organic matter (POM) during carbon remineralization [Johnson et al., 1997], the particle scavenging removal dissolved $\mathrm{Fe}$ [Bergquist and Boyle, 2006; Bergquist et al., 2007], and the complexation of $\mathrm{Fe}$ with natural organic ligands [Gledhill and van den Berg, 1994; Rue and Bruland, 1995; Kuma et al., 1996, 2003; Laglera and van den Berg, 2009; Kitayama et al., 2009]. These processes would lead to mid depth maxima and, below that, a slight decrease in the [D-Fe] with depth in deep water of the North Pacific Ocean [Martin et al., 1989; Johnson et al., 1997; Nakabayashi et al., 2001; Nishioka et al., 2003, 2007; Takata et al., 2006; Kitayama et al., 2009]. Recently, it has been suggested that Fe(III) hydroxide solu- 
bility in deep water is controlled by organic Fe(III) complexation with humic-type fluorescent dissolved organic matter (humic-type FDOM), which plays an important role in regulating $[\mathrm{D}-\mathrm{Fe}]$ in the deep water column [Tani et al., 2003; Laglera and van den Berg, 2009; Kitayama et al., 2009; Yamashita et al., 2010]. However, particulate $\mathrm{Fe}$ ([P-Fe]: total dissolvable $\mathrm{Fe}([\mathrm{T}-\mathrm{Fe}])$ minus $[\mathrm{D}-\mathrm{Fe}])$ with short residence time in deep water may be sensitive to change in the water masses and the resuspension of sediments from the seafloor or the slope in various oceanic sites [Takata et al., 2006, 2008; Nishioka et al., 2007; Lam and Bishop, 2008; Otosaka et al., 2008; Kitayama et al., 2009; Fujita et al., 2010].

[4] Ecosystems in marginal seas are in close proximity to terrestrial and continental shelf sources of Fe. Iron is generally supplied to surface water by the upwelling, vertical water mixing, atmospheric and riverine inputs [e.g., Hutchins et al., 1998; Kuma et al., 2000; de Baar and de Jong, 2001; Jickells and Spokes, 2001; Saitoh et al., 2008]. Recently, it has been reported that the supply of iron from continental shelf sediments to the surface water by wind-driven upwelling induced the high productivity in central California waters [Johnson et al., 1999, 2001; Fitzwater et al., 2003; Elrod et al., 2004, 2008; Chase et al., 2005]. In addition, several studies in other regions, such as the Alaskan coast, the east coast of New Zealand, the European shelf and the Pacific Ocean side of Hokkaido (Japan), have also reported that the lateral supply of iron from the continental margin is an important source to the open ocean [Croot and Hunter, 1998; Laës et al., 2003, 2007; Lam et al., 2006; Lam and Bishop, 2008; Ussher et al., 2007; Nakayama et al., 2010]. However, the transport mechanisms and the magnitudes of the various sources in the iron cycles of the coastal and marginal seas are not well known.

[5] In the present study, we report the vertical distributions of iron ([D-Fe] and $[\mathrm{T}-\mathrm{Fe}]$ ), and chemical components (humic-type fluorescence intensity (humic $\mathrm{F}$ intensity), nutrient, and oxygen concentrations) throughout the water column in the continental shelf, slope and basin regions (the Chukchi Sea and the Canada Basin) of the western Arctic Ocean in order to understand the mechanisms that control iron behavior in the water column of the Arctic Ocean.

\section{Methods}

\subsection{Sample Collections and Treatment}

[6] Samples were collected during cruise (MR 08-04) on the Japanese R/V Mirai between 1 and 27 September 2008 in the western Arctic Ocean (Figure 1). Twenty-three to ten seawater samples were vertically collected between 5 and $3897 \mathrm{~m}$ at one station (B1) in the Canada Basin, between 5 and $1283-2143 \mathrm{~m}$ at four stations (B2, B3, S2 and S5) in the slope region and between 5 and $186-217 \mathrm{~m}$ at three stations (S1, S3 and S4) in the continental shelf region of the Chukchi Sea (Table 1). The distance between S2 and B2, between B2 and $\mathrm{B} 3$ and between $\mathrm{S} 4$ and $\mathrm{S} 5$ is approximately $280-300 \mathrm{~km}$. In addition, a basin station (B1) in the Canada Basin is away from the continental shelf with distance of about $200 \mathrm{~km}$ (Figure 1). We used acid-cleaned, Teflon-coated, 10 L Niskin $\mathrm{X}$ sampling bottles (General Oceanics) attached to a CTD-RMS (conductivity-temperature-depth probe-rosette multi-sampler). Sample filtration for analyses of [D-Fe] and humic $\mathrm{F}$ intensity was carried out by connecting an acid-cleaned $0.22 \mu \mathrm{m}$ pore size Durapore membrane filter (Cartridge type-Millipak 100 with large filtering surface area, Millipore) to a sampling bottle spigot and then filtering with gravity filtration. The filtrate $(7-8 \mathrm{ml})$ for humic $\mathrm{F}$ intensity analysis was immediately frozen in $10 \mathrm{ml}$ acrylics tubes to $<-20^{\circ} \mathrm{C}$ in the dark until measurement in the laboratory. The freezing treatment was used to prevent the possible microbial degradation of natural humic-type FDOM in the filtered seawater. Unfiltered samples were collected for [T-Fe], chlorophyll $a(\mathrm{Chl} a)$ and nutrient concentrations. The filtered and unfiltered seawater $(100 \mathrm{ml}$ in precleaned $125 \mathrm{ml}$ low-density polyethylene (LDPE) bottles) used for $[\mathrm{D}-\mathrm{Fe}](<0.22 \mu \mathrm{m}$ fraction $)$ and $[\mathrm{T}-\mathrm{Fe}]$ (unfiltered) analyses were acidified with ultrapure grade $\mathrm{HCl}$ to $\mathrm{pH} 1.7-1.8$ in a class 100 clean air bench on board after collection. The acidified iron samples were allowed to stand at room temperature for 3 months at least until iron analysis in the laboratory [Bruland and Rue, 2001; Lohan et al., 2005].

[7] Hydrographic observations (salinity, temperature, depth and dissolved oxygen (DO) concentration) were conducted with a CTD and DO sensor.

\subsection{Dissolved and Total Dissolvable Fe Concentrations}

[8] The acidified iron samples were buffered at $\mathrm{pH} 3.2$ with a $8.15 \mathrm{M}$ quartz-distilled formic acid $-4.54 \mathrm{M}$ ultrapure grade ammonium buffer solution $(0.8 \mathrm{ml}$ per $100 \mathrm{ml}$ sample solution) in a class 100 clean air bench in the laboratory. The iron concentrations ([D-Fe] and [T-Fe]) in buffered $0.22 \mu \mathrm{m}$ filtered and unfiltered samples were determined by an automated Fe analyzer (Kimoto Electric Co. Ltd.) by use of a combination of chelating resin concentration and luminolhydrogen peroxide chemiluminescence (CL) detection in a closed flow through system [Obata et al., 1993] as reported in our previous studies [Nakabayashi et al., 2001; Takata et al., 2004, 2005, 2006, 2008; Kitayama et al., 2009]. Briefly, iron in a buffered sample solution was selectively collected on 8-hydroxyquinoline immobilized chelating resin and then eluted with dilute $0.3 \mathrm{~N} \mathrm{HCl}$. The eluent was mixed with luminol solution, $0.6 \mathrm{~N}$ aqueous ammonia and $0.7 \mathrm{M} \mathrm{H}_{2} \mathrm{O}_{2}$ solution successively, and then the mixture was introduced into the CL cell. Finally, the iron concentration was determined from the CL intensity. Accuracy of this analysis was checked using the SAFe reference materials $(\mathrm{pH} 1.7-1.8)$. The SAFe reference materials were found to be within the range of the consensus values of $0.097 \pm 0.043 \mathrm{nM}$ for $\mathrm{S} 1$ and $0.91 \pm 0.17 \mathrm{nM}$ for D2 [Johnson, 2007] (GEOTRACES homepage, http://www.geotraces.org/). The [D-Fe] of S1 and D2 reference samples, which were determined by our analytical method after being buffered at $\mathrm{pH} 3.2$ in the present study, were $0.113 \pm 0.004 \mathrm{nM}$ and $0.99 \pm 0.09 \mathrm{nM}$ within the range of the consensus values, respectively.

[9] In our previous studies, there were no differences in the [D-Fe] of directly buffered $0.22 \mu \mathrm{m}$ filtered oceanic samples to $\mathrm{pH} 3.2$ (without acidification of seawater samples to $\mathrm{pH}$ $1.7-1.8$ in the present study) that had been kept for 1 month and 6 months (for example, 0.28 and $0.27 \mathrm{nM}$ at $50 \mathrm{~m}$ depth and 1.10 and $1.09 \mathrm{nM}$ at $200 \mathrm{~m}$ depth, respectively, at an oceanic station in the northwestern North Pacific Ocean [Takata et al., 2004]). However, it is unclear what the effect of weak acidification to $\mathrm{pH} 3.2$ would have on solubilizing 


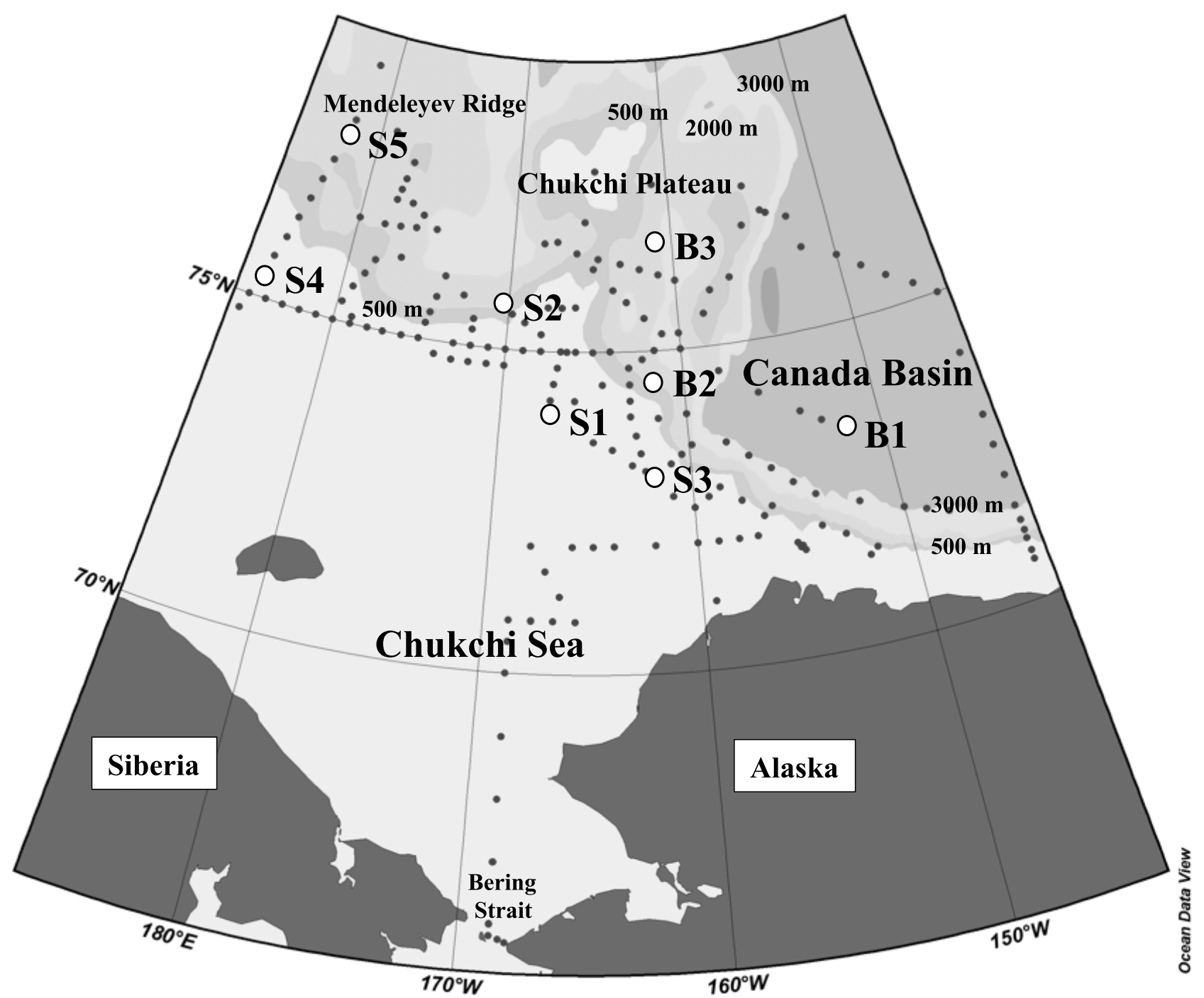

Figure 1. Locations of sampling stations in the Canada Basin (B1) and in the Chukchi Sea (B2, B3, S2, and S5 in the slope region and S1, S3, and S4 in the shelf region) of the western Arctic Ocean during 1-27 September 2008.

any colloidal $\mathrm{Fe}$ phases that might be present in the "dissolved" fraction ([D-Fe], <0.22 $\mu \mathrm{m}$ fraction), an uncertainty of great concern especially in estuarine and coastal waters, where dissolved Fe concentrations may be higher and colloidal Fe comprises a greater fraction [Bruland and Rue, 2001]. In addition, the weak acidification of unfiltered seawater samples may lead to measure some operational fraction of the acid leachable particulate $\mathrm{Fe}$ and dissolved $\mathrm{Fe}$ fraction. Therefore, the filtered and unfiltered seawater used for [D-Fe] and [T-Fe] analyses in the present study were acidified with ultrapure $\mathrm{HCl}$ to $\mathrm{pH} 1.7-1.8$ on board as soon as the samples were collected and then kept at room temperature for 3 months at least until iron analysis in the laboratory.

\subsection{Humic-Type FDOM, Nutrient, Dissolved Oxygen and Chl $\boldsymbol{a}$ Concentrations}

[10] The frozen $0.22 \mu \mathrm{m}$ filtered samples in acrylics tubes were thawed and warmed overnight to room temperature in the dark, the humic-type FDOM was measured as the humic F intensity in a $1 \mathrm{~cm}$ quartz cell with a Hitachi F-2000 fluo- rescence spectrophotometer at $320 \mathrm{~nm}$ excitation and $420 \mathrm{~nm}$ emission, using $10 \mathrm{~nm}$ bandwidths [Hayase et al., 1988; Hayase and Shinozuka, 1995] as reported in previous studies [Tani et al., 2003; Takata et al., 2004, 2005; Kitayama et al.,

Table 1. Position of Stations B1 to S5, Bottom Depth and Sampling Date in the Canada Basin and the Chukchi Sea of the Western Arctic Ocean

\begin{tabular}{|c|c|c|c|c|}
\hline \multirow[b]{2}{*}{ Station } & \multicolumn{2}{|c|}{ Position } & \multirow{2}{*}{$\begin{array}{l}\text { Bottom Pressure } \\
\text { (dbar) }\end{array}$} & \multirow[b]{2}{*}{ Sampling Date } \\
\hline & Latitude (N) & Longitude & & \\
\hline \multicolumn{5}{|c|}{ Basin and Slope Regions } \\
\hline B1 & $73^{\circ} 24^{\prime}$ & $152^{\circ} 00^{\prime} \mathrm{W}$ & 3897 & 1 Sep 2008 \\
\hline B2 & $74^{\circ} 30^{\prime}$ & $162^{\circ} 00^{\prime} \mathrm{W}$ & 1645 & 11 Sep 2008 \\
\hline B3 & $76^{\circ} 36^{\prime}$ & $161^{\circ} 10^{\prime} \mathrm{W}$ & 2153 & 13 Sep 2008 \\
\hline $\mathrm{S} 2$ & $75^{\circ} 38^{\prime}$ & $170^{\circ} 26^{\prime} \mathrm{W}$ & 1393 & 19 Sep 2008 \\
\hline S5 & $77^{\circ} 40^{\prime}$ & $177^{\circ} 40^{\prime} \mathrm{E}$ & 1293 & 27 Sep 2008 \\
\hline \multicolumn{5}{|c|}{ Shelf Region } \\
\hline $\mathrm{S} 1$ & $73^{\circ} 58^{\prime}$ & $167^{\circ} 35^{\prime} \mathrm{W}$ & 217 & 18 Sep 2008 \\
\hline S3 & $73^{\circ} 10^{\prime}$ & $162^{\circ} 20^{\prime} \mathrm{W}$ & 196 & 23 Sep 2008 \\
\hline S4 & $75^{\circ} 20^{\prime}$ & $175^{\circ} 20^{\prime} \mathrm{E}$ & 222 & 26 Sep 2008 \\
\hline
\end{tabular}




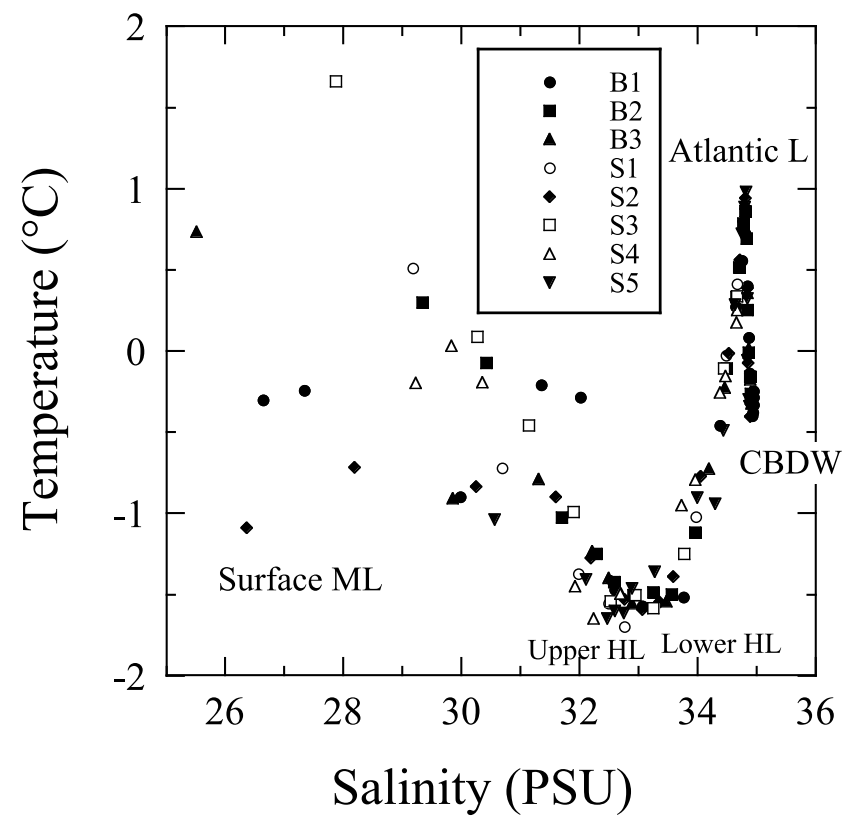

Figure 2. Temperature-salinity diagram during 1-27 September 2008. Classification of five water masses: (1) surface mixed layer (surface ML) with salinities of 24-31 and temperatures of $-1-4.6^{\circ} \mathrm{C},(2)$ cold upper halocline layer (upper HL) from $\sim 25$ to $\sim 225 \mathrm{~m}$ with characteristic salinities of 32-34 and temperatures of -1.0 to $-1.7^{\circ} \mathrm{C}$, (3) lower halocline layer (lower HL) with salinities ranging from about 34.2 to 34.6 beneath the upper HL, (4) Atlantic layer (AL) with salinities of 34.6-34.85 and temperatures of $0.3-$ $0.7^{\circ} \mathrm{C}$, and (5) Canada basin deep water (CBDW) with salinities $>34.85$ and temperatures $<0^{\circ} \mathrm{C}$.

2009]. Fluorescent intensity was expressed in terms of quinine sulfate units $(1 \mathrm{QSU}=1 \mathrm{ppb}$ quinine sulfate in $0.05 \mathrm{M}$ $\mathrm{H}_{2} \mathrm{SO}_{4}$, excitation $320 \mathrm{~nm}$, emission $420 \mathrm{~nm}$ ) [Mopper and Schultz, 1993]. Major nutrient concentrations were mea- sured using a Bran \& Luebbe TRAACS 800 system. Dissolved oxygen (DO, $\mathrm{O}_{2}$ measured) was determined by the Winkler titration method. The apparent oxygen utilization (AOU) was calculated by subtracting the measured oxygen content $\left(\mathrm{O}_{2}\right.$ measured $)$ from the saturation value $\left(\mathrm{O}_{2}\right.$ sat $)$ of the dissolved oxygen [Hansen, 1999]. Chl $a$ concentrations were determined by the fluorometric method and a Turner Design fluorometer (10-AU-005). Nutrient and Chl $a$ concentrations and DO were measured on board by Marine Works Japan on behalf of Japan Marine Science and Technology Center (JAMSTEC).

\section{Results}

\subsection{Hydrographic Features}

[11] Surface water salinity was generally lower over the southern Canada Basin region (B1, B2, B3, S1, S2 and S3, $\mathrm{S}=23.97-27.88)$ compared with the western shelf and slope regions (S4 and S5, S = 29.22-30.57), resulting from the sea ice melting during summer in 2008 (Figures 1-4). The temperature-salinity diagram (Figure 2) identified three water masses in the shelf region (S1, S3 and S4 with the bottom depth of about $200 \mathrm{~m}$ ) and five water masses in the slope and basin regions (B1, B2, B3, S2 and S5), similar to those in previous studies [Aagaard et al., 1981; Swift et al., 1997; Codispoti et al., 2005]. (1) The surface mixed layer from the surface to $\sim 25-50 \mathrm{~m}$ with salinities of 24-31 and temperatures of $-1-4.6^{\circ} \mathrm{C}$ depending on season and location, which receives most inputs of freshwater from rivers and melting ice. (2) The cold upper HL from $\sim 25$ to $\sim 225 \mathrm{~m}$ in the slope and basin regions (Figure 3 ) and from $\sim 25$ to $\sim 150 \mathrm{~m}$ in the shelf region (Figure 4) with characteristic salinities of 32-34 and temperatures of -1.0 to $-1.7^{\circ} \mathrm{C}$ (Figure 2), which mainly derived from low-salinity Pacific-origin water that enters via Bering Strait. (3) The lower HL with salinities ranging from about 34.2 to 34.6 (Figure 2), which mainly originates from the Atlantic, beneath the upper HL [Macdonald et al., 2004]. (4) The Atlantic layer (AL) with salinities of 34.6-34.85 and temperatures of $0.3-0.7^{\circ} \mathrm{C}$ extending from about $250-850 \mathrm{~m}$.

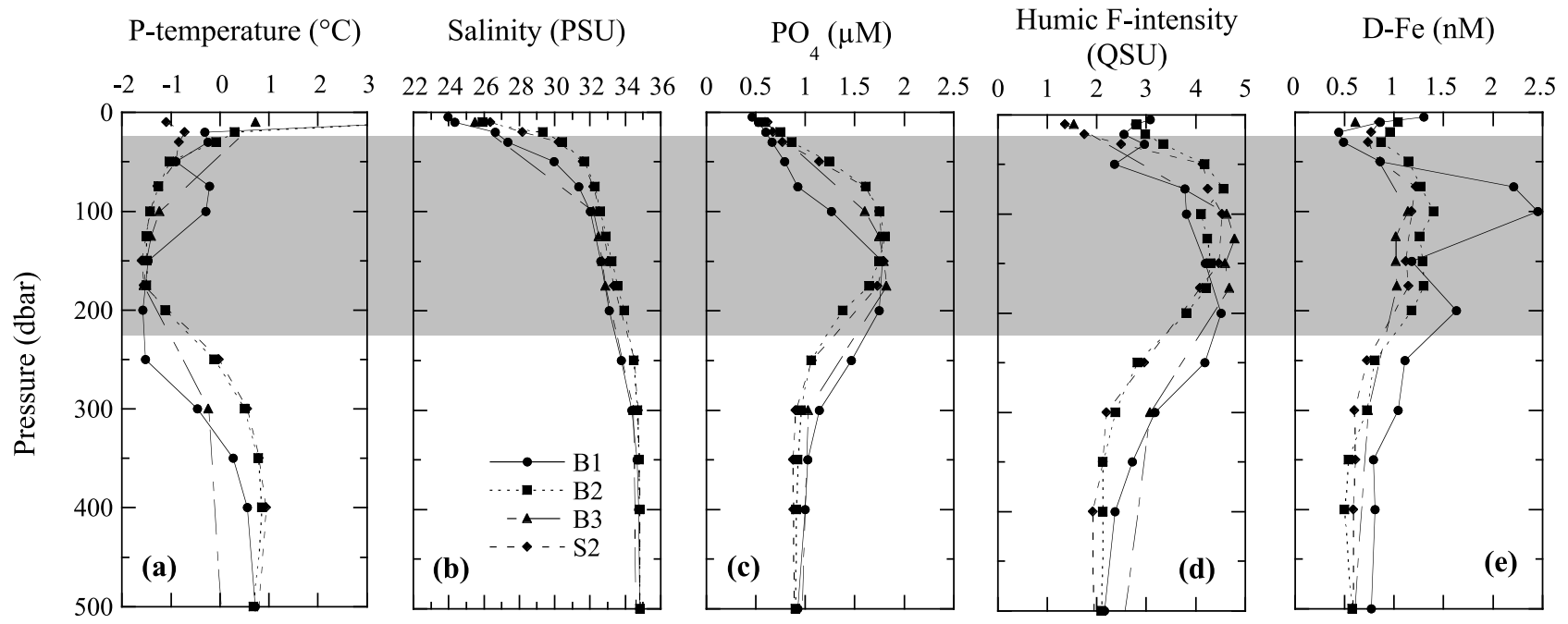

Figure 3. Vertical profiles of (a) potential temperature, (b) salinity, (c) phosphate, (d) humic F intensity, and (e) [D-Fe] in the surface water at B1, B2, B3, and S2 of the slope and basin regions. The shaded region is the halocline layer characterized by a temperature minimum and phosphate maximum. 


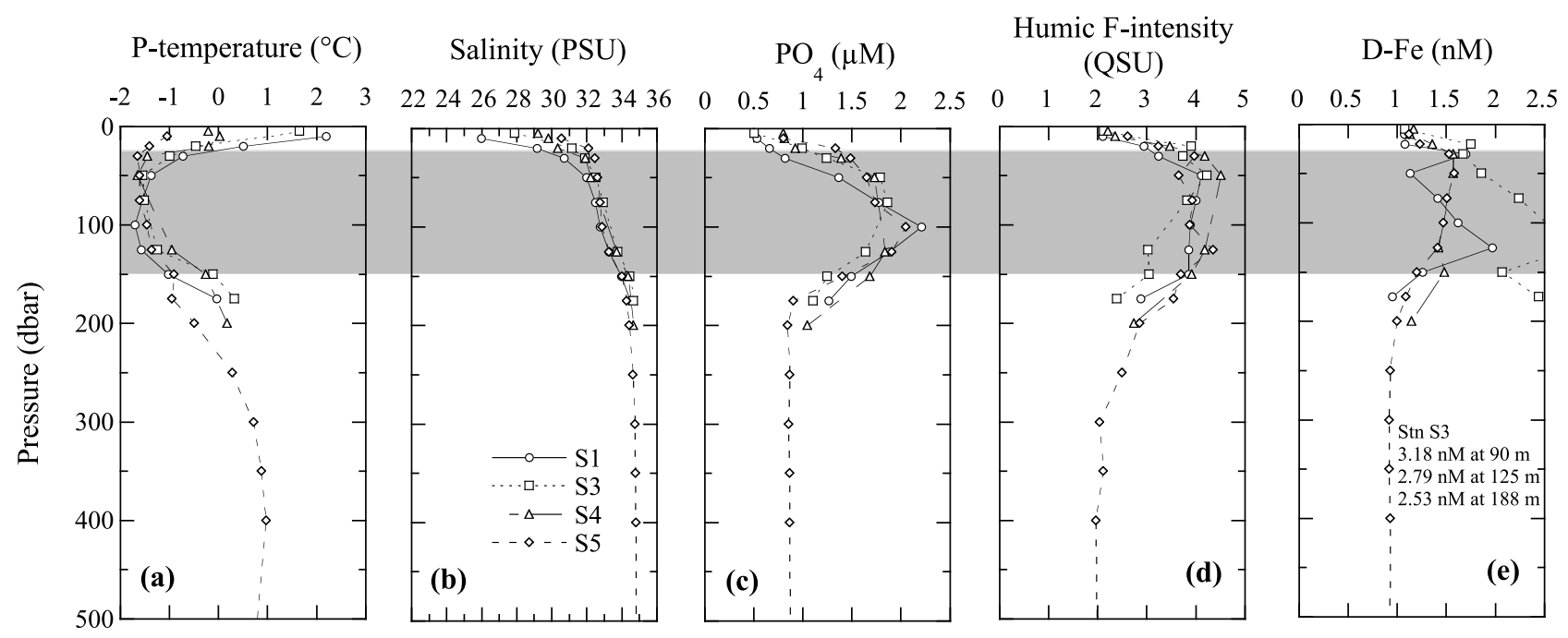

Figure 4. Vertical profiles of (a) potential temperature, (b) salinity, (c) phosphate, (d) humic F intensity, and (e) [D-Fe] in the surface water at S1, S3, and S4 of the shelf region and at S5 of the slope region, where is located in the west of the Chukchi Plateau. The shaded region is the halocline layer characterized by a temperature minimum and phosphate maximum.

Humic F-intensity (QSU) and $\mathrm{PO}_{4}(\mu \mathrm{M})$

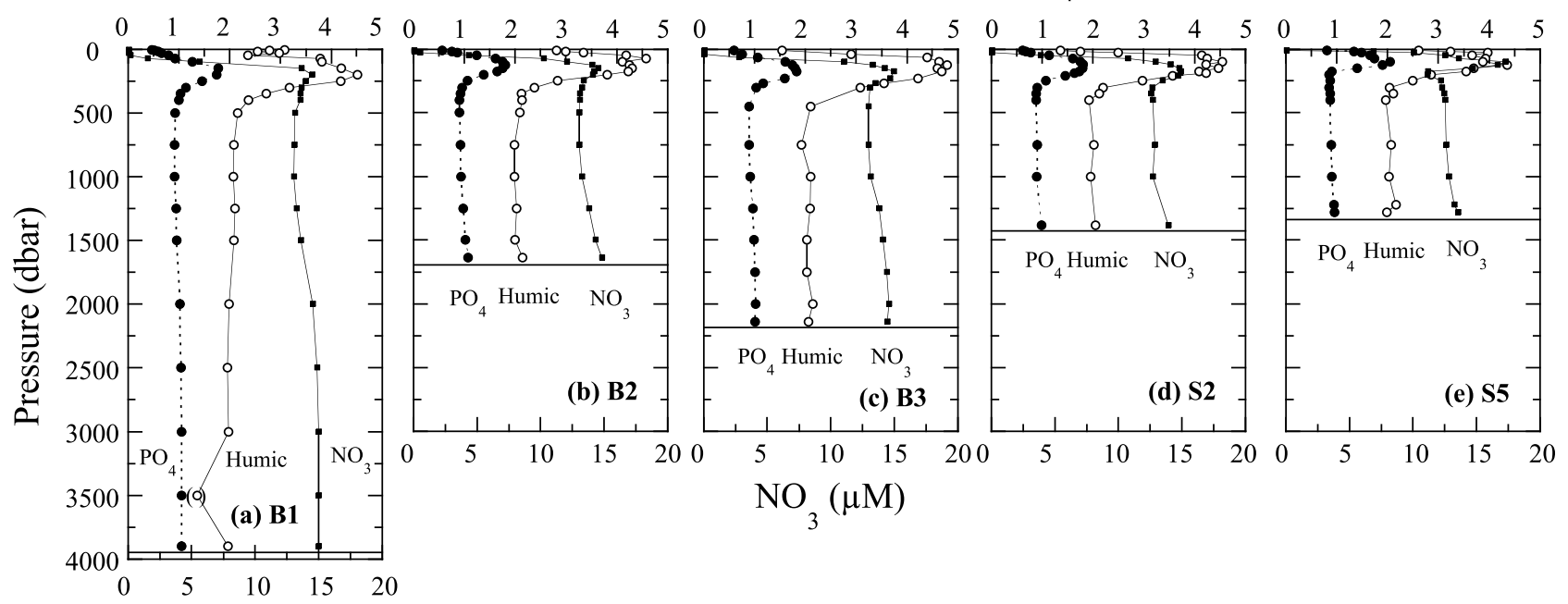

Figure 5. Vertical profiles of nutrients $\left(\mathrm{NO}_{3}\right.$ and $\left.\mathrm{PO}_{4}\right)$ and humic $\mathrm{F}$ intensity throughout the water column at (a) B1, (b) B2, (c) B3, (d) S2, and (e) S5 of the slope and basin regions. 


\section{Humic F-intensity (QSU) and $\mathrm{PO}_{4}(\mu \mathrm{M})$}
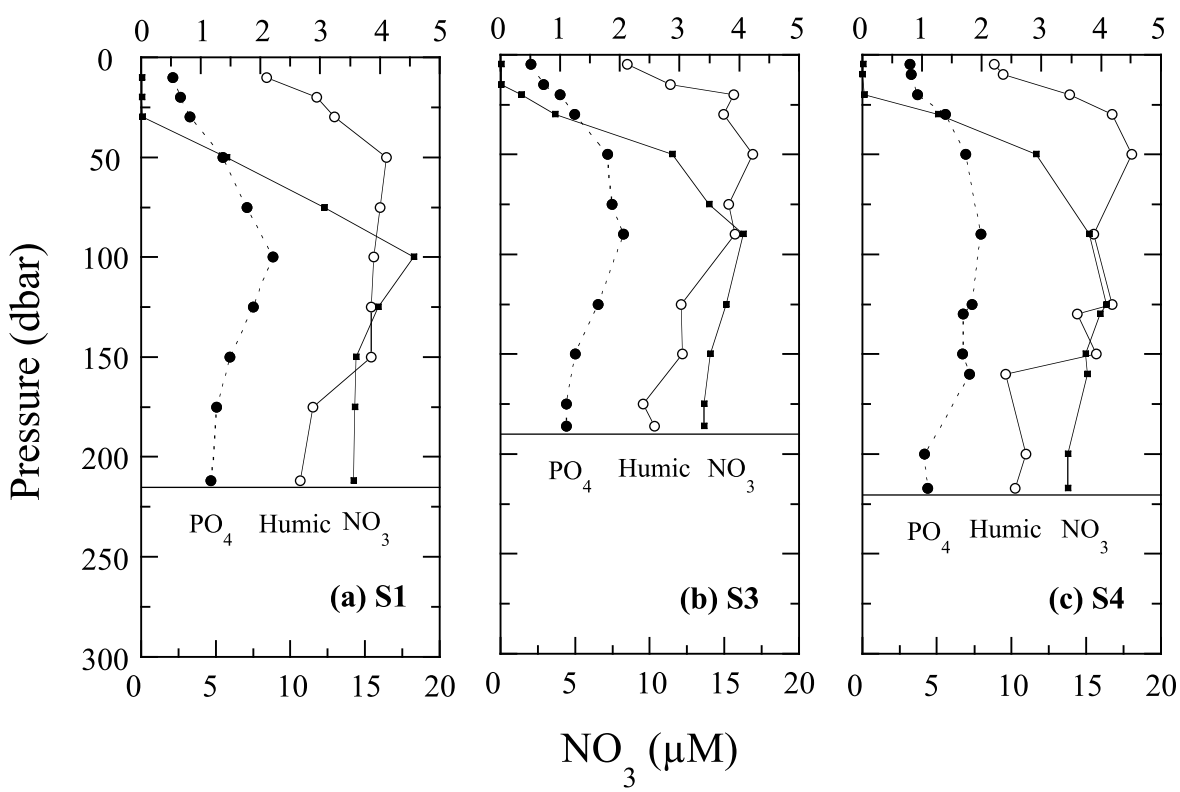

Figure 6. Vertical profiles of nutrients $\left(\mathrm{NO}_{3}\right.$ and $\left.\mathrm{PO}_{4}\right)$ and humic $\mathrm{F}$ intensity throughout the water column at (a) S1, (b) S3, and (c) S4 of the shelf region.

(5) The Canadian Basin Deep Water (CBDW) at depths greater than $850-1000 \mathrm{~m}$ with salinities $>34.85$ and temperatures $<0^{\circ} \mathrm{C}$ having properties similar to those of the Atlantic inflow through the Fram Strait [Swift et al., 1997; Codispoti et al., 2005].

\subsection{Iron and Other Chemical Components in the Surface Water}

[12] In the surface mixed layer ( $<25-50 \mathrm{~m}$ depth), nutrient concentrations at all stations, except for S5, were extremely low for nitrate and relatively high phosphate and silicate $\left(0.05-0.15 \mu \mathrm{M}\right.$ for $\mathrm{NO}_{3}, 0.5-0.8 \mu \mathrm{M}$ for $\mathrm{PO}_{4}$ (Figures $3 \mathrm{c}, 4 \mathrm{c}$, 5 , and 6 and Table 2) and 3-7 $\mu \mathrm{M}$ for $\mathrm{Si}(\mathrm{OH})_{4}$ (Table 2)), while those at S5, where is in the west of the Chukchi Plateau (Figure 1), were relatively high with $0.06-6.88 \mu \mathrm{M}$ for $\mathrm{NO}_{3}$ (Figure 5e), 0.8-1.3 $\mu \mathrm{M}$ for $\mathrm{PO}_{4}$ (Figures $4 \mathrm{c}$ and 5e), 11$16 \mu \mathrm{M}$ for $\mathrm{Si}(\mathrm{OH})_{4}$ (Table 2). Similarly, Chl $a$ concentrations at S5 were relatively high with $0.9-1.6 \mu \mathrm{g}^{-1}$, while those at other stations were low with $0.1-0.8 \mu \mathrm{g} \mathrm{l}^{-1}$ (Figure 7). In addition, humic $\mathrm{F}$ intensity in the surface mixed layer was also low and followed by an increase with depth (Figures 3d, $4 \mathrm{~d}, 5$, and 6). However, [D-Fe] and [T-Fe] levels were relatively high with the ranges of $0.44-1.3 \mathrm{nM}$ and $2-8 \mathrm{nM}$, respectively (Figures 3e, 4e, 8, and 9 and Table 2).

[13] In the halocline layer (upper HL and lower HL, $\sim 25 \mathrm{~m}$ to $200-350 \mathrm{~m}$ ), nutrient concentrations and humic $\mathrm{F}$ intensity generally increased from the surface to the bottom of the upper HL ( $\sim 25 \mathrm{~m}$ to $225 \mathrm{~m}$ at the slope and basin regions and $\sim 25 \mathrm{~m}$ to $\sim 150 \mathrm{~m}$ at the shelf region) ranged from 0.0 to $\sim 15-18 \mu \mathrm{M}$ for $\mathrm{NO}_{3}$, from 0.5 to $\sim 1.8-2.2 \mu \mathrm{M}$ for $\mathrm{PO}_{4}$, from 5 to $\sim 32-54 \mu \mathrm{M}$ for $\mathrm{Si}(\mathrm{OH})_{4}$ (Table 2) and from 2-3 to $\sim 4.1-4.8$ for humic $\mathrm{F}$ intensity and, below that, rapidly decreased with depth in the lower HL (Figures 3c, 3d, 4c, 4d,
5, and 6 and Table 2). The highest nutrient concentrations were generally found in the upper HL between depths of about $125-200 \mathrm{~m}$ of the slope and basin regions (B1, B2, B3, and S2, Figures $3 \mathrm{c}$ and 5) and about $90-125 \mathrm{~m}$ of the shelf region (S1, S3, S4, and S5 (slope region), Figures 4c, 5, and 6). The higher $[\mathrm{D}-\mathrm{Fe}]$ values at each station were also found in the upper HL (Figures $3 e$ and $4 \mathrm{e}$ and Table 2). The [D-Fe] levels in the halocline layer at B1, S1 and S3 were relatively variable in the range of 1.0-3.2 nM, while those at B2, B3, S2, S4 and S5 rapidly increased from surface to about 50-75 m depth, nearly constant with high concentrations of 1.0 $1.6 \mathrm{nM}$ between depths of about 75-175 $\mathrm{m}$ in the upper HL, and rapidly decreased with depth in the lower HL (Figures 3e, $4 \mathrm{e}, 8$, and 9). However, the higher $[\mathrm{T}-\mathrm{Fe}]([\mathrm{T}-\mathrm{Fe}]=[\mathrm{P}-\mathrm{Fe}]$ plus $[\mathrm{D}-\mathrm{Fe}],[\mathrm{T}-\mathrm{Fe}] \gg[\mathrm{D}-\mathrm{Fe}]$ ) levels were found near the lower HL of the slope and basin regions and near bottom of the shelf region (Figures 8 and 9). The [T-Fe] of the slope and basin regions rapidly increased with depth from surface to near the lower HL to $10-50 \mathrm{nM}$ (approximately $30-50 \mathrm{nM}$ at $\mathrm{B} 1$ and $\mathrm{B} 2,20 \mathrm{nM}$ at B3 and $\mathrm{S} 2$ and $10 \mathrm{nM}$ at S5) between depths of $100-300 \mathrm{~m}$, and rapidly decreased with depth to 10-20 nM beneath the lower HL (Figure 8). In addition, those of the shelf region rapidly increased with depth to $512 \mathrm{nM}$ at $212 \mathrm{~m}$ depth near bottom (S1: bottom depth of $217 \mathrm{~m}$ ), to $312 \mathrm{nM}$ at $186 \mathrm{~m}$ depth near bottom (S3: bottom depth of $196 \mathrm{~m}$ ) and to $243 \mathrm{nM}$ at $217 \mathrm{~m}$ depth near bottom (S4: bottom depth of $222 \mathrm{~m}$ ) (Figure 9 and Table 2).

\subsection{Iron and Other Chemical Components in the Deep Water Column}

[14] Nutrient concentrations and humic $F$ intensity in the water column of the slope and basin regions (Figure 5) were generally characterized by surface depletion, subsurface 
Table 2. D-Fe, T-Fe, Humic F Intensity and Nutrient Concentrations and N:D-Fe Molar Ratio in the Surface Water ( $\leq 500 \mathrm{~m}$ Depth) of the Western Arctic Ocean

\begin{tabular}{|c|c|c|c|c|c|c|c|c|}
\hline Depth $(\mathrm{db})$ & $\mathrm{D}-\mathrm{Fe}(\mathrm{nM})$ & $\mathrm{T}-\mathrm{Fe}(\mathrm{nM})$ & Humic (QSU) & $\mathrm{NO}_{3}(\mu \mathrm{M})$ & $\mathrm{NO}_{2}(\mu \mathrm{M})$ & $\mathrm{Si}(\mathrm{OH})_{4}(\mu \mathrm{M})$ & $\mathrm{PO}_{4}(\mu \mathrm{M})$ & $\mathrm{N}: \mathrm{D}-\mathrm{Fe}^{\mathrm{a}}$ (molar ratio) \\
\hline \multicolumn{9}{|c|}{ Station B1 (Basin Region) } \\
\hline 5 & 1.30 & 5.2 & 3.08 & 0.05 & 0.01 & 3.85 & 0.463 & 46 \\
\hline 10 & 0.86 & 4.7 & 2.79 & 0.05 & 0.00 & 3.32 & 0.526 & 58 \\
\hline 20 & 0.44 & 3.1 & 2.55 & 0.06 & 0.00 & 2.79 & 0.601 & 136 \\
\hline 30 & 0.49 & 4.3 & 2.97 & 0.05 & 0.01 & 3.06 & 0.664 & 122 \\
\hline 50 & 0.86 & 4.6 & 2.36 & 0.18 & 0.05 & 5.46 & 0.794 & 267 \\
\hline 75 & 0.58 & 11.9 & 3.78 & 1.52 & 0.08 & 10.19 & 0.926 & 2760 \\
\hline 100 & 2.21 & 19.2 & 3.81 & 5.62 & 0.06 & 16.28 & 1.267 & 2570 \\
\hline 150 & 2.45 & 7.7 & 4.20 & 13.66 & 0.01 & 28.52 & 1.777 & 5580 \\
\hline 200 & 1.18 & 34.0 & 4.51 & 14.50 & 0.04 & 30.96 & 1.744 & 12,300 \\
\hline 250 & 1.63 & 31.0 & 4.18 & 13.98 & 0.02 & 24.39 & 1.463 & 8590 \\
\hline 300 & 1.11 & 29.7 & 3.18 & 13.63 & 0.02 & 15.08 & 1.139 & 12,300 \\
\hline 350 & 1.04 & 19.8 & 2.72 & 13.57 & 0.01 & 12.35 & 1.026 & 13,100 \\
\hline 400 & 0.79 & 46.1 & 2.37 & 13.54 & 0.01 & 10.66 & 0.997 & 17,200 \\
\hline 500 & 0.81 & 19.1 & 2.16 & 13.15 & 0.01 & 8.08 & 0.924 & 16,200 \\
\hline \multicolumn{9}{|c|}{ Station B2 (Slope Region) } \\
\hline 10 & 1.04 & 6.0 & 2.81 & 0.05 & 0.00 & 3.52 & 0.564 & 48 \\
\hline 20 & 0.96 & 3.7 & 2.99 & 0.06 & 0.01 & 4.74 & 0.751 & 73 \\
\hline 30 & 0.87 & 3.1 & 3.35 & 0.49 & 0.02 & 5.14 & 0.864 & 586 \\
\hline 50 & 1.15 & 3.0 & 4.18 & 4.35 & 0.07 & 12.41 & 1.244 & 3840 \\
\hline 75 & 1.27 & 6.8 & 4.57 & 10.24 & 0.06 & 24.05 & 1.613 & 8110 \\
\hline 100 & 1.40 & 18.7 & 4.11 & 12.05 & 0.10 & 30.23 & 1.754 & 8680 \\
\hline 125 & 1.26 & 26.4 & 4.24 & 14.06 & 0.09 & 32.30 & 1.804 & 11,200 \\
\hline 150 & 1.29 & 30.5 & 4.30 & 14.51 & 0.02 & 31.27 & 1.746 & 11,300 \\
\hline 175 & 1.30 & 47.7 & 4.22 & 14.23 & 0.01 & 28.95 & 1.646 & 11,000 \\
\hline 200 & 1.18 & 39.0 & 3.81 & 14.09 & 0.01 & 21.93 & 1.378 & 11,900 \\
\hline 250 & 0.81 & 19.4 & 2.83 & 13.39 & 0.01 & 13.45 & 1.061 & 16,500 \\
\hline 300 & 0.73 & 17.0 & 2.38 & 13.27 & 0.01 & 9.93 & 0.954 & 18,200 \\
\hline 350 & 0.54 & 17.4 & 2.12 & 13.09 & 0.01 & 7.99 & 0.923 & 24,300 \\
\hline 400 & 0.50 & 19.2 & 2.13 & 13.07 & 0.00 & 7.45 & 0.906 & 26,100 \\
\hline 500 & 0.58 & 14.1 & 2.09 & 13.03 & 0.01 & 7.30 & 0.904 & 22,500 \\
\hline \multicolumn{9}{|c|}{ Station B3 (Slope Region) } \\
\hline 10 & 0.61 & 4.8 & 1.54 & 0.04 & 0.00 & 2.77 & 0.592 & 66 \\
\hline 40 & 0.64 & 2.3 & 2.90 & 0.04 & 0.00 & 4.34 & 0.755 & 63 \\
\hline 65 & 1.13 & 2.6 & 4.40 & 2.76 & 0.40 & 9.23 & 1.064 & 2800 \\
\hline 100 & 1.14 & 5.2 & 4.63 & 11.05 & 0.01 & 22.42 & 1.606 & 9700 \\
\hline 125 & 1.02 & 7.9 & 4.79 & 13.31 & 0.01 & 27.34 & 1.749 & 13,100 \\
\hline 150 & 1.02 & 10.0 & 4.60 & 14.24 & 0.00 & 29.90 & 1.795 & 14,000 \\
\hline 175 & 1.03 & 12.4 & 4.68 & 14.94 & 0.00 & 32.10 & 1.824 & 14,500 \\
\hline 230 & 1.01 & 20.7 & 4.22 & 14.67 & 0.01 & 27.66 & 1.595 & 14,500 \\
\hline 270 & 0.79 & 15.1 & 3.55 & 13.53 & 0.01 & 16.72 & 1.172 & 17,100 \\
\hline 300 & 0.74 & 12.5 & 3.08 & 13.10 & 0.00 & 13.26 & 1.030 & 17,700 \\
\hline 450 & 0.46 & 12.7 & 2.11 & 12.96 & 0.00 & 7.35 & 0.892 & 28,200 \\
\hline \multicolumn{9}{|c|}{ Station S1 (Shelf Region) } \\
\hline 10 & 1.07 & 25.8 & 2.10 & 0.06 & 0.01 & 2.15 & 0.533 & 65 \\
\hline 20 & 1.08 & 7.6 & 2.94 & 0.05 & 0.01 & 2.70 & 0.663 & 56 \\
\hline 30 & 1.70 & 9.6 & 3.24 & 0.10 & 0.01 & 3.35 & 0.817 & 65 \\
\hline 50 & 1.13 & 5.4 & 4.11 & 5.73 & 0.11 & 16.58 & 1.365 & 5170 \\
\hline 75 & 1.41 & 8.7 & 4.00 & 12.26 & 0.13 & 31.44 & 1.772 & 8790 \\
\hline 100 & 1.62 & 20.8 & 3.89 & 18.27 & 0.09 & 46.75 & 2.210 & 11,300 \\
\hline 125 & 1.97 & 58.9 & 3.85 & 15.88 & 0.05 & 37.20 & 1.880 & 8090 \\
\hline 150 & 1.26 & 62.9 & 3.85 & 14.40 & 0.02 & 25.88 & 1.491 & 11,400 \\
\hline 175 & 0.95 & 121.3 & 2.88 & 14.31 & 0.02 & 20.69 & 1.267 & 15,100 \\
\hline 212 & 1.11 & 511.6 & 2.66 & 14.21 & 0.06 & 19.51 & 1.169 & 12,900 \\
\hline \multicolumn{9}{|c|}{ Station S2 (Slope Region) } \\
\hline 10 & 0.85 & 6.3 & 1.36 & 0.03 & 0.00 & 2.71 & 0.622 & 35 \\
\hline 20 & 0.77 & 4.5 & 1.75 & 0.02 & 0.00 & 2.99 & 0.676 & 26 \\
\hline 30 & 0.74 & 3.4 & 2.50 & 0.06 & 0.01 & 3.84 & 0.769 & 95 \\
\hline 50 & 0.86 & 2.4 & 4.14 & 3.86 & 0.47 & 10.66 & 1.139 & 5030 \\
\hline 75 & 1.22 & 4.2 & 4.25 & 10.75 & 0.01 & 21.92 & 1.607 & 8820 \\
\hline 100 & 1.18 & 6.6 & 4.54 & 12.91 & 0.01 & 26.38 & 1.746 & 10,900 \\
\hline 120 & 1.08 & 8.0 & 4.23 & 14.08 & 0.01 & 29.52 & 1.802 & 13,000 \\
\hline 150 & 1.12 & 13.0 & 4.47 & 14.76 & 0.01 & 31.39 & 1.798 & 13,200 \\
\hline 175 & 1.15 & 17.7 & 4.09 & 14.89 & 0.01 & 30.16 & 1.731 & 13,000 \\
\hline 190 & 0.99 & 20.7 & 4.22 & 14.87 & 0.01 & 28.45 & 1.638 & 15,000 \\
\hline 210 & 0.81 & 20.3 & 3.56 & 14.68 & 0.01 & 25.11 & 1.455 & 18,100 \\
\hline
\end{tabular}


Table 2. (continued)

\begin{tabular}{|c|c|c|c|c|c|c|c|c|}
\hline Depth (db) & D-Fe (nM) & $\mathrm{T}-\mathrm{Fe}(\mathrm{nM})$ & Humic (QSU) & $\mathrm{NO}_{3}(\mu \mathrm{M})$ & $\mathrm{NO}_{2}(\mu \mathrm{M})$ & $\mathrm{Si}(\mathrm{OH})_{4}(\mu \mathrm{M})$ & $\mathrm{PO}_{4}(\mu \mathrm{M})$ & $\mathrm{N}: \mathrm{D}-\mathrm{Fe}^{\mathrm{a}}$ (molar ratio) \\
\hline 250 & 0.73 & 16.5 & 2.97 & 13.44 & 0.01 & 15.65 & 1.069 & 18,400 \\
\hline 300 & 0.60 & 8.9 & 2.20 & 12.67 & 0.00 & 8.93 & 0.904 & 21,100 \\
\hline 350 & 0.61 & 7.9 & 2.12 & 12.57 & 0.00 & 6.79 & 0.877 & 20,600 \\
\hline 400 & 0.59 & 8.7 & 1.92 & 12.71 & 0.00 & 6.86 & 0.883 & 21,500 \\
\hline \multicolumn{9}{|c|}{ Station S3 (Shelf Region) } \\
\hline 5 & 1.08 & 10.3 & 2.12 & 0.03 & 0.00 & 5.18 & 0.508 & 28 \\
\hline 15 & 1.42 & 10.7 & 2.84 & 0.04 & 0.01 & 7.06 & 0.722 & 35 \\
\hline 20 & 1.75 & 10.7 & 3.91 & 1.41 & 0.03 & 7.95 & 0.996 & 823 \\
\hline 30 & 1.67 & 6.7 & 3.74 & 3.66 & 0.06 & 13.48 & 1.242 & 2830 \\
\hline 50 & 1.86 & 13.4 & 4.22 & 11.50 & 0.15 & 33.32 & 1.791 & 6260 \\
\hline 75 & 2.24 & 27.2 & 3.82 & 13.97 & 0.13 & 36.08 & 1.863 & 6290 \\
\hline 90 & 3.18 & 94.3 & 3.93 & 16.26 & 0.09 & 42.65 & 2.061 & 5140 \\
\hline 125 & 2.79 & 115.5 & 3.03 & 15.10 & 0.07 & 30.40 & 1.640 & 5440 \\
\hline 150 & 2.07 & 166.4 & 3.05 & 14.05 & 0.08 & 18.65 & 1.250 & 6830 \\
\hline 175 & 2.44 & 282.1 & 2.39 & 13.65 & 0.08 & 14.35 & 1.106 & 5630 \\
\hline 186 & 2.53 & 312.3 & 2.58 & 13.65 & 0.08 & 14.28 & 1.107 & 5820 \\
\hline \multicolumn{9}{|c|}{ Station S4 (Shelf Region) } \\
\hline 5 & 1.17 & 2.9 & 2.21 & 0.04 & 0.01 & 3.57 & 0.803 & 43 \\
\hline 10 & 1.13 & 2.4 & 2.36 & 0.03 & 0.01 & 4.27 & 0.816 & 35 \\
\hline 20 & 1.36 & 4.3 & 3.47 & 0.13 & 0.01 & 6.77 & 0.927 & 103 \\
\hline 30 & 1.57 & 2.7 & 4.18 & 5.08 & 0.08 & 10.72 & 1.392 & 3290 \\
\hline 50 & 1.57 & 3.1 & 4.51 & 11.66 & 0.11 & 26.28 & 1.731 & 7500 \\
\hline 90 & 1.65 & 12.8 & 3.88 & 15.23 & 0.09 & 36.15 & 1.987 & 9290 \\
\hline 125 & 1.42 & 11.8 & 4.18 & 16.35 & 0.06 & 37.18 & 1.837 & 11,600 \\
\hline 130 & 1.39 & 12.3 & 3.60 & 15.93 & 0.04 & 33.12 & 1.686 & 11,500 \\
\hline 150 & 1.48 & 16.3 & 3.92 & 14.94 & 0.04 & 45.68 & 1.683 & 10,100 \\
\hline 160 & 1.55 & 25.1 & 2.40 & 15.07 & 0.02 & 54.35 & 1.793 & 9740 \\
\hline 200 & 1.15 & 51.7 & 2.74 & 13.78 & 0.05 & 20.20 & 1.046 & 12,000 \\
\hline 217 & 1.08 & 242.8 & 2.56 & 13.78 & 0.07 & 24.15 & 1.095 & 12,800 \\
\hline \multicolumn{9}{|c|}{ Station S5 (Slope Region) } \\
\hline 10 & 1.12 & 5.6 & 2.61 & 0.06 & 0.00 & 10.65 & 0.805 & 54 \\
\hline 20 & 1.23 & 5.2 & 3.24 & 6.88 & 0.28 & 15.71 & 1.335 & 5820 \\
\hline 30 & 1.53 & 7.6 & 3.97 & 10.05 & 0.07 & 19.03 & 1.487 & 6610 \\
\hline 50 & 1.58 & 7.8 & 3.66 & 12.53 & 0.04 & 22.86 & 1.655 & 7960 \\
\hline 75 & 1.51 & 6.6 & 3.93 & 13.60 & 0.01 & 24.28 & 1.739 & 9010 \\
\hline 100 & 1.47 & 9.8 & 3.87 & 17.28 & 0.02 & 36.85 & 2.052 & 11,800 \\
\hline 125 & 1.41 & 8.6 & 4.35 & 16.66 & 0.02 & 36.52 & 1.905 & 11,800 \\
\hline 150 & 1.20 & 8.5 & 3.69 & 14.71 & 0.01 & 25.22 & 1.402 & 12,300 \\
\hline 175 & 1.09 & 8.0 & 3.55 & 11.16 & 0.00 & 10.04 & 0.902 & 10,200 \\
\hline 200 & 1.00 & 6.0 & 2.86 & 11.15 & 0.00 & 8.07 & 0.847 & 11,200 \\
\hline 250 & 0.93 & 6.3 & 2.50 & 12.18 & 0.00 & 7.71 & 0.869 & 13,100 \\
\hline 300 & 0.92 & 6.8 & 2.04 & 12.28 & 0.00 & 6.09 & 0.856 & 13,300 \\
\hline 400 & 0.92 & 8.7 & 2.11 & 12.43 & 0.00 & 5.96 & 0.868 & 13,500 \\
\hline
\end{tabular}

${ }^{\mathrm{a}} \mathrm{N}: \mathrm{D}-\mathrm{Fe}$ molar ratio is $\left(\left[\mathrm{NO}_{3}\right]+\left[\mathrm{NO}_{2}\right]\right) /[\mathrm{D}-\mathrm{Fe}]$.

maxima (14.5-17.3 $\mu \mathrm{M}$ for $\mathrm{NO}_{3}, 1.8-2.1 \mu \mathrm{M}$ for $\mathrm{PO}_{4}, 31-$ $32 \mu \mathrm{M}$ for $\mathrm{Si}(\mathrm{OH})_{4}$ and 4.4-4.8 QSU for humic F intensity) in the upper HL ( 25 to $225 \mathrm{~m}$ ), rapid decrease with depth in the lower HL ( 225 to $350 \mathrm{~m})$, and then gradual decrease with depth in the AL $(300-850 \mathrm{~m})$ to $12.3-13.1 \mu \mathrm{M}$ for $\mathrm{NO}_{3}$, $0.86-0.91 \mu \mathrm{M}$ for $\mathrm{PO}_{4}, 6.0-7.4 \mu \mathrm{M}$ for $\mathrm{Si}(\mathrm{OH})_{4}$ and 2.02.1 QSU for humic F intensity. In deep and bottom waters below $850 \mathrm{~m}$ depth (CBDW), nutrient concentrations slightly increased with depth $\left(13.6-15.0 \mu \mathrm{M}\right.$ for $\mathrm{NO}_{3}, 0.95-1.07 \mu \mathrm{M}$ for $\mathrm{PO}_{4}, 8.7-15 \mu \mathrm{M}$ for $\mathrm{Si}(\mathrm{OH})_{4}$ near bottom), while humic $\mathrm{F}$ intensity were remarkably uniform with 2.0-2.2 QSU throughout the deep water column. These vertical distributions and levels were similar among the stations in the slope and basin regions (Figure 5).

[15] The [D-Fe] in the water column of the slope and basin regions (Figure 8 ) were generally characterized by surface depletion, subsurface maxima (1.1-2.5 nM) in the upper HL, rapid decrease with depth in the lower HL, and then gradual decrease with depth in the AL to $0.4-0.6 \mathrm{nM}$ at B1, B2, B3 and $\mathrm{S} 2$ and to $\sim 0.9 \mathrm{nM}$ at S5. In deep and bottom waters below $850 \mathrm{~m}$ depth (CBDW), the [D-Fe] levels tended to slightly decrease with depth to $0.25 \mathrm{nM}$ at $3500 \mathrm{~m}$ depth of $\mathrm{B} 1$ and to $0.28 \mathrm{nM}$ at $2143 \mathrm{~m}$ depth (near bottom) of B3 (Figures $8 \mathrm{a}$ and $8 \mathrm{c}$ ) or to be nearly uniform with $\sim 0.5-0.6 \mathrm{nM}$ at B2 and S2 (Figures $8 \mathrm{~b}$ and $8 \mathrm{~d}$ ) and with $\sim 0.9-1.1 \mathrm{nM}$ at S5 (Figure 8e). These vertical distributions were relatively similar among the stations in the slope and basin regions (Figure 8) and remarkably similar to those of nutrient concentrations and humic $\mathrm{F}$ intensity (Figure 5). In addition, the [T-Fe] at B1, B2, B3, S2, and S5 (Figures 8) were also generally characterized by surface depletion $(\sim 2-6 \mathrm{nM})$, rapid increase with depth in the upper HL, subsurface maxima $(\sim 10-48 \mathrm{nM})$ in the lower HL, and then rapid decrease with depth in the AL to $\sim 6-14 \mathrm{nM}$. In deep and bottom waters (CBDW), the [T-Fe] levels tended to gradually decrease with depth to $2.6 \mathrm{nM}$ at $3500 \mathrm{~m}$ depth of $\mathrm{B} 1,9.7 \mathrm{nM}$ at $1500 \mathrm{~m}$ 


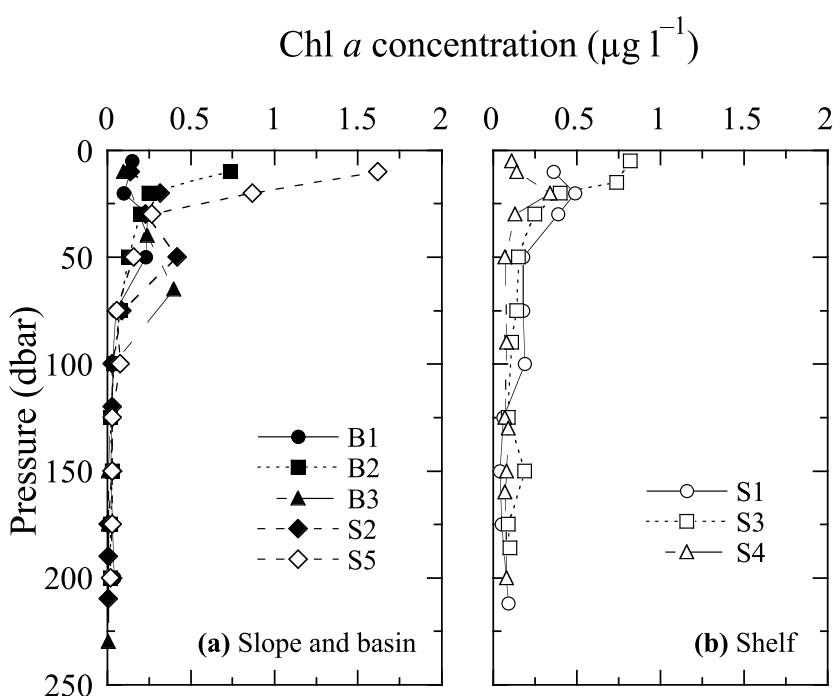

Figure 7. Vertical profiles of Chl $a$ concentration in the surface water (a) at B1, B2, B3, S2, and S5 of the slope and basin regions and (b) at $\mathrm{S} 1, \mathrm{~S} 3$, and $\mathrm{S} 4$ of the shelf region.

depth of B2 and $7.4 \mathrm{nM}$ at $1500 \mathrm{~m}$ depth of B3 and appeared to rapidly increase with depth in bottom waters $(5.8 \mathrm{nM}$ and 21-66 nM near bottom depth in the basin region (B1) and the slope region (B2, B3, S2, and S5), respectively).

\section{Discussion}

\subsection{Iron Concentrations in the Surface Water}

[16] We observed extremely low nitrate, relatively low Chl $a$ and relatively high Fe concentrations (0.44-1.3 nM for [D-Fe] and 2-8 nM for [T-Fe]) in the surface mixed layer at all stations, except for S5 (Figures 3-9). Therefore, phytoplankton growth in the surface mixed layer of the Arctic Ocean in the present study, which was characterized by low nitrate and high Fe concentrations, could be limited by macronutrient deficiency. The high Fe concentrations in the surface mixed layer probably result from the high Fe inputs from rivers and melting ice to nutrient-depleted surface water. In our previous studies [Kitayama et al., 2009; Fujita et al., 2010], we observed high [D-Fe] and [T-Fe] in the surface mixed layer with extremely low nutrient concentrations at the stations of the western subtropical North Pacific and the marginal Japan Sea, probably resulting from higher atmospheric Fe input than biological Fe uptake in the oligotrophic surface mixed layer. However, it is unknown which particulate $\mathrm{Fe}([\mathrm{P}-\mathrm{Fe}]=[\mathrm{T}-\mathrm{Fe}]$ minus $[\mathrm{D}-\mathrm{Fe}])$ in the surface mixed layer of the present study is reactive POM and/or inert particles from river and melting ice.

[17] In the present study, the subsurface maxima of humic $F$ intensity (4-5 QSU, Figures 3d and 4d) and of [D-Fe] (1.0$3.2 \mathrm{nM}$, Figures $3 \mathrm{e}$ and $4 \mathrm{e})$ were found at the narrow depth ranges of 25-150 $\mathrm{m}(\mathrm{S} 1, \mathrm{~S} 3$ and $\mathrm{S} 4$ in the shelf region and S5 in the slope region) and 25-225 $\mathrm{m}(\mathrm{B} 1, \mathrm{~B} 2, \mathrm{~B} 3$, and S2 in the slope and basin regions) in the upper HL, remarkably consistent with those of nutrient concentrations (Figures $3 c, 4 c$, 5, and 6). The halocline in the Canada Basin is complex, reflecting inputs of both Pacific- and Atlantic-origin waters. Pacific Winter Water (PWW) through the Bering Strait has long been recognized as primary component of the western Arctic halocline [Coachman et al., 1975; Shimada et al., 2005; Woodgate and Aagaard, 2005]. In winter, minimal biological uptake of nutrients occurs in the Bering and Chukchi Seas [Hansell et al., 1993; Codispoti et al., 2005], and nutrients are supplied from the shelf bottom [Jones and Anderson, 1986], resulting in extremely high nutrient concentrations in PWW. The spreading of PWW into the western Arctic Ocean forms a nutrient maximum layer [Moore et al., 1983; Jones and Anderson, 1986]. In addition, many recent studies of nutrient and dissolved organic matter in the western Arctic Ocean [Jones et al., 1998; Wang et al., 2006; Guéguen et al., 2007; Nishino et al., 2008, 2009; Yamamoto-Kawai et al., 2008] have also reported prominent nutrient and colored dissolved organic matter (CDOM) maxima in the upper

Dissolved Fe concentration (D-Fe, nM)

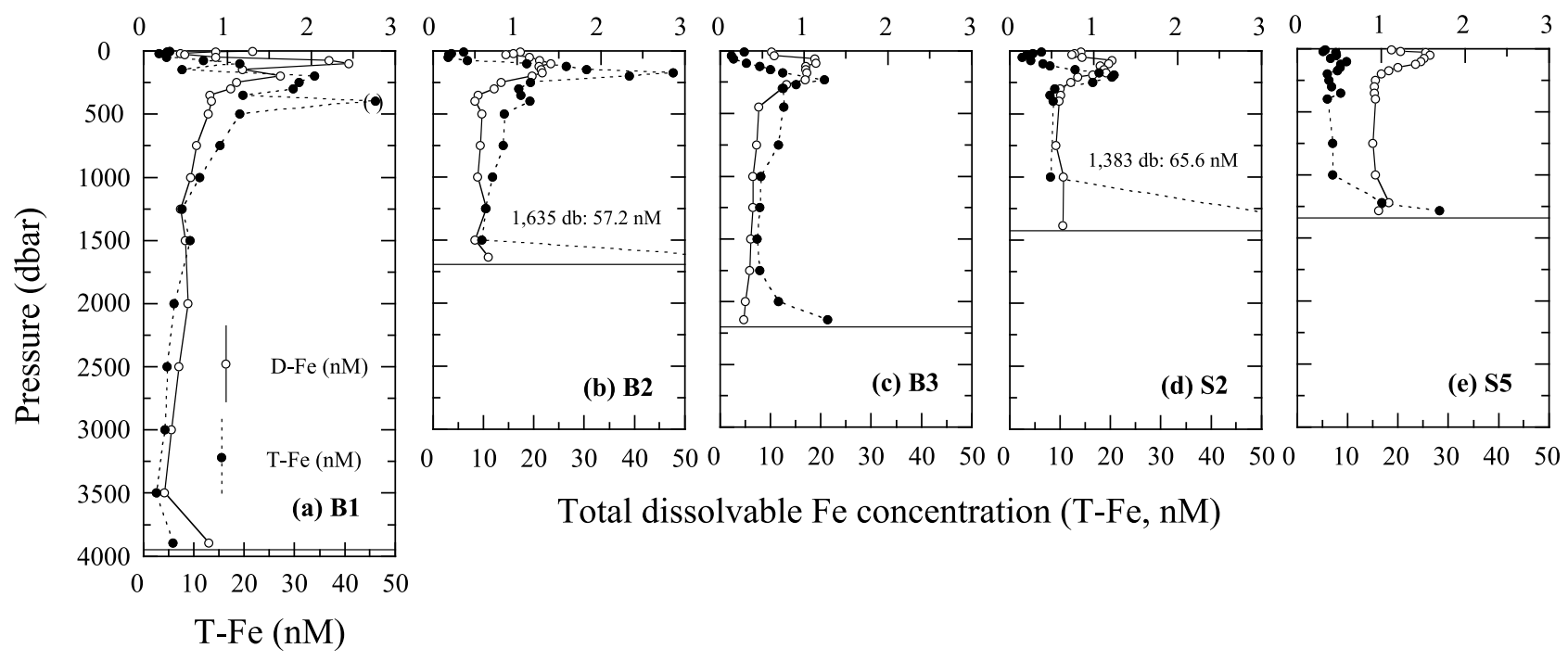

Figure 8. Vertical profiles of iron ([D-Fe] and [T-Fe]) throughout the water column at (a) B1, (b) B2, (c) B3, (d) S2, and (e) S5 of the slope and basin regions. 


\section{Dissolved Fe concentration (D-Fe, nM)}

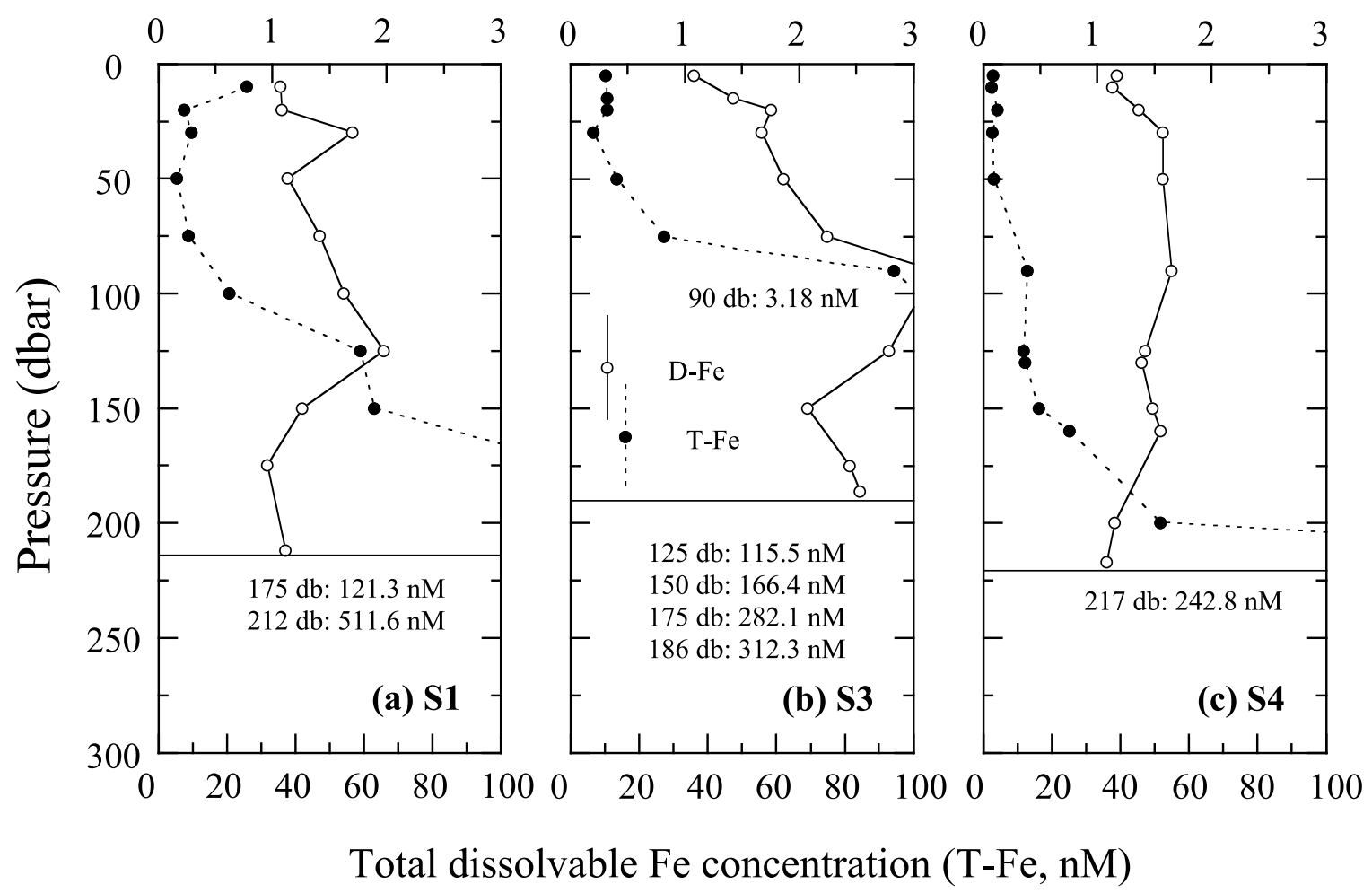

Figure 9. Vertical profiles of iron ([D-Fe] and [T-Fe]) throughout the water column at (a) S1, (b) S3, and (c) S4 of the shelf region.

HL. Wang et al. [2006] reported that nutrient concentrations were in the surface depletion and the subsurface maxima centered at $\sim 125 \mathrm{~m}$ depth within the halocline layer and that both ammonium and phosphate concentrations were elevated in shelf bottom waters, indicating a possible nutrient source from sediments, and in a plume that extended into the upper HL offshore. In addition, it has been reported that nutrient maximum concentrations were found above the sediments on the shallower shelf and shelf-slope break $(\leq \sim 100 \mathrm{~m}$ depth) than the shelf region in the present study, indicating potential sedimentary sources, and that ammonium with the highest concentrations in bottom waters over the self and at the shelfslope break decreased from the shelf region to the basin region, showing little variation with depth in the basin region [Wang et al., 2006; Guéguen et al., 2007]. Moreover, it has been suggested that penetration of the high nutrient and CDOM fluorescence signals, which were formed on the shelves, into the Canada Basin was confined to the upper $\mathrm{HL}$ and the presence of nutrient and CDOM in the halocline layer likely resulted from two main processes: the brine rejection during sea ice formation and transport across the sediment-water interface during early diagenesis [Jones and Anderson, 1986; Guéguen et al., 2007]. Therefore, the high concentrations of [D-Fe] and humic-type FDOM as humic F intensity within the halocline waters of the shelf, slope and basin regions would be due to sea ice formation and interactions with sediments on the shallower shelves $(\leq \sim 100 \mathrm{~m}$ depth) than the shelf region in the present study. Since these processes could be sources of the $[\mathrm{D}-\mathrm{Fe}]$ and humic-type
FDOM, these subsurface lateral transports into the halocline layer from the shelves to the Arctic Basin could be expected.

[18] However, the maxima of [T-Fe] were found in the lower HL, beneath the upper HL, of the slope and basin regions, except for S5, (Figure 8) and at the bottom of the shelf region (Figure 9) although those of [D-Fe], nutrient and humic F intensity were found in the upper HL (Figures 3-6, 8, and 9) and the [D-Fe] in the upper HL appeared to be associated with humic $\mathrm{F}$ intensity. It has been suggested that oxidative decomposition of particulate organic matter in continental shelf sediments is likely to be the major benthic source of $[\mathrm{D}-\mathrm{Fe}]$ and $[\mathrm{P}-\mathrm{Fe}]$ to the overlying water on shelves [Johnson et al., 1999; Elrod et al., 2004; Nédélec et al., 2007; Saitoh et al., 2008]. In the present study, the subsurface maxima of [D-Fe] in the upper HL and the increase in [T-Fe] with depth in the shelf regions (Figure 9) may be attributed to the balance between the supply of dissolved pore water iron from shelf sediments to the overlying water, the oxidative precipitation of dissolved iron, the resuspension of sedimentary particles into a benthic layer due to a tidal mixing and the inflow of the Atlantic water into the lower HL. The higher $[\mathrm{P}-\mathrm{Fe}]$ levels were found with subsurface maxima in the lower HL of the slope and basin regions (Figure 8) and near the bottom of the shelf region with increase with depth (Figure 9), indicating that the $[\mathrm{P}-\mathrm{Fe}]$ in the lower $\mathrm{HL}$ is probably exported from the highly productive shelf region to the slope and basin regions. Therefore, the high $[\mathrm{P}-\mathrm{Fe}]$ in the lower HL is predominantly due to the sediment resuspension on the shelves ( $\geq \sim 100 \mathrm{~m}$ depth) by the inflow of the Atlantic water (Figure 2). Shelf sediment is generally rich in organic 

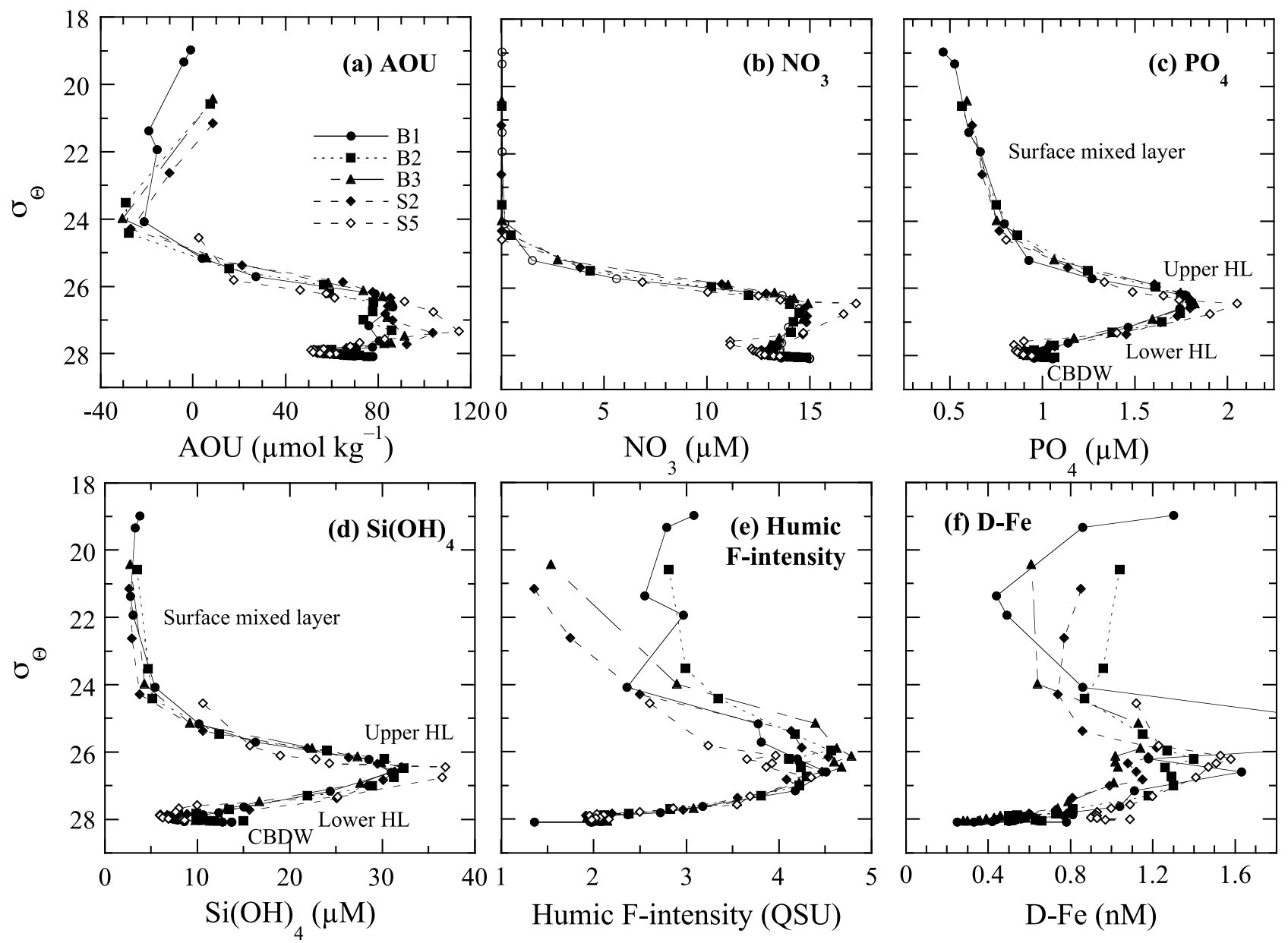

Figure 10. (a) $\mathrm{AOU}$, nutrient ((b) $\mathrm{NO}_{3}$, (c) $\mathrm{PO}_{4}$, and (d) $\left.\mathrm{Si}(\mathrm{OH})_{4}\right)$, (e) humic $\mathrm{F}$ intensity, and (f) [D-Fe] versus potential density $\left(\sigma_{\theta}\right)$ at $\mathrm{B} 1, \mathrm{~B} 2, \mathrm{~B} 3, \mathrm{~S} 2$, and $\mathrm{S} 5$ of the slope and basin regions.

matter, which consists of fresh phytoplankton detritus and fluvial deposition. Under this organic-rich and -reduced condition in the sediments, soluble $\mathrm{Fe}^{2+}$ and organic $\mathrm{Fe}(\mathrm{III})$ complexes are formed by microbial degradation process [Luther et al., 1992, 1996; Nevin and Lovley, 2002; Carey and Taillefert, 2005]. These soluble Fe species are probably supplied from shelf sediment to the overlying water and are mostly oxidized and precipitated in seawater. In addition, it has been reported that the cold and turbid Dense Shelf Water (DSW) in the Okhotsk Sea is discharged from the bottom of the northwestern continental shelf, where sea ice formation had rejected large amounts of brine waters in winter, to the pelagic intermediate layer, supplying large amounts of particulate matter [Nakatsuka et al., 2002, 2004]. It was suggested that the sedimentary particles are resuspended into the benthic layer, forming an extremely cold and turbid water mass, due to the tidal mixing and then are exported from the shelf to the slope area.

[19] Since Fe is preferentially scavenged from the water column during the mineralization cycle, upwelled water is relatively deficient in $\mathrm{Fe}$ compared to nitrogen species. Therefore, an additional input of $\mathrm{Fe}$ is needed to surface waters to reestablish the biologically required N:D-Fe balance. We used a maximum stochiometric mole ratio of $\mathrm{N}: \mathrm{D}-$ $\mathrm{Fe}$ required to allow the complete consumption of $\mathrm{N}$ of
15000:1 [Kaupp et al., 2011], which was calculated by assuming a limiting $\mathrm{C}: \mathrm{Fe}$ ratio in phytoplankton of $10^{5}: 1$ [Sunda and Huntsman, 1995] and a C:N ratio of 6.7:1. The upper and lower HL in the present study have the N:D-Fe ratio $<15000: 1$ (Table 2), implying the presence of sufficient D-Fe to allow full utilization of nitrate in the HL.

[20] Profiles of AOU, nutrient, humic F intensity and [D-Fe] against potential density $\left(\sigma_{\theta}\right)$ showed a well developed halocline in a $\sigma_{\theta}$ range of 25.0-27.5 and the maximum values at a narrow $\sigma_{\theta}$ range of 26-27 in all stations of the slope and basin regions (Figure 10). However, we observed relatively higher nutrient and $\mathrm{Chl} a$ concentrations (0.1$6.9 \mu \mathrm{M}$ for $\mathrm{NO}_{3}, 0.8-1.3 \mu \mathrm{M}$ for $\mathrm{PO}_{4}, 11-16 \mu \mathrm{M}$ for $\mathrm{Si}(\mathrm{OH})_{4}$ and $0.9-1.6 \mu \mathrm{g} \mathrm{l}^{-1}$ for Chl $a$, Table 2 and Figure 7a) at the surface (10-20 m depths) and higher maximum AOU and nutrient concentrations at $\sigma_{\theta}=26-27$ in the shallower halocline layer (25 to $150 \mathrm{~m}$ depth) at S5, where is in the west of the Chukchi Plateau (Figure 1), than other slope and basin stations around the southwestern Canada Basin (Table 2 and Figures 10a-10d). In the context of nutrient supply and biological activities, nutrient plumes from the Gulf of Anadyr move into the southwestern Chukchi Sea via the Bering Strait in summer. This nutrient-rich water of the Chukchi Sea is identified as Western Chukchi Summer Water (WCSW), being assumed to spread into the west of the Chukchi Plateau 
[Shimada et al., 2001, 2005; Steele et al., 2004]. The highnutrient WCSW is carried eastward along the Chukchi Sea shelf slope and contributed to the high biological productivity [Hill and Cota, 2005]. In contrast, nutrient-poor Eastern Chukchi Summer Water (ECSW), which is originated from low-nutrient Alaskan Coastal Water along the Alaskan cost, flows into the Canada Basin via the Bering Strait [Shimada et al., 2001]. Therefore, higher nutrient and Chl $a$ concentrations at the surface and higher maximum AOU and nutrient concentrations in the shallower halocline layer at S5 than other stations are probably attributed to the inflow of nutrient-rich WCSW into the west of the Chukchi Plateau [Nishino et al., 2008, 2009].

\subsection{Iron Concentrations in the Deep Water Column}

[21] In deep and bottom waters below about $750 \mathrm{~m}$ depth (CBDW), [D-Fe] levels were relatively uniform with 0.4 $0.6 \mathrm{nM}$ and $0.9-1.1 \mathrm{nM}$ at the depths between $750 \mathrm{~m}$ and $1500 \mathrm{~m}$ at B1, B2, B3, and S2 and at S5, respectively. Below $1500 \mathrm{~m}$ depth, these slightly decreased with depth to $0.25 \mathrm{nM}$ at $3500 \mathrm{~m}$ depth of $\mathrm{B} 1$ and to $0.28 \mathrm{nM}$ at $2143 \mathrm{~m}$ depth (near bottom) of B3 (Figures $8 \mathrm{a}$ and $8 \mathrm{c}$ ). These low [D-Fe] values may be due to the low concentrations of humic DOM (Figures 5a and 5c). The vertical distributions of [D-Fe] in the deep water column were relatively similar to those of humic $F$ intensity with almost uniform value of $\sim 2$ QSU in deep water and slight decrease with depth below $1500 \mathrm{~m}$ depth, rather than nutrient concentrations with slight increase with depth (Figure 5). However, [D-Fe] levels in deep water at S5 were approximately 2 times higher than those at other slope and basin stations (Figure 8), probably resulting from the higher biological productivity at the surface water and the higher production of dissolved $\mathrm{Fe}$ from the microbial decomposition of sinking particulate organic matter in deep water of S5 than the other slope and basin stations [Nishino et al., 2008, 2009]. The remineralization of biogenic particles release iron, and this process is responsible for the vertical distribution of iron. The high $[\mathrm{D}-\mathrm{Fe}]$ from the biological decomposition in deep water of S5 may contain a large amount of colloidal $\mathrm{Fe}(<0.22 \mu \mathrm{m}$ size $)$. It has been reported that dissolved $\mathrm{Fe}$ $(<0.4 \mu \mathrm{m}$ size $)$ in the North Atlantic Deep Water decreased by $30 \%$ from the North Atlantic to the South Atlantic site with most of the decrease due to loss of colloidal Fe fraction ( 0.02 $0.4 \mu \mathrm{m}$ size) and that dissolved and colloidal Fe concentrations in deep water vary between water masses depending on the source, age, and path of the water masses [Bergquist et al., 2007]. In addition, recent several studies of iron distributions revealed that $[\mathrm{D}-\mathrm{Fe}]$ are about 2 times higher $(0.8-1.5 \mathrm{nM})$ in deep waters in the western North Pacific [Nakabayashi et al., 2001; Nishioka et al., 2003, 2007; Takata et al., 2006; Kitayama et al., 2009] than $(0.5-0.6 \mathrm{nM})$ in the central North Pacific [Takata et al., 2006; Kitayama et al., 2009], $(0.5-0.7 \mathrm{nM})$ around station P in the Gulf of Alaska [Martin et al., 1989; Nishioka et al., 2003] and (0.4-0.5 nM) at the VERTEX-IV site in the center of the North Pacific subtropical gyre [Bruland et al., 1994]. This probably reflects the regional patterns of the eolian source, physical transport, and the water column cycling of iron, such as biological uptake, remineralization of biogenic organic matter, scavenging onto particles, and iron complexation with organic ligands [Johnson et al., 1997]. Kitayama et al. [2009] suggested that the decrease in $[\mathrm{D}-\mathrm{Fe}]$ in the deep water column from the western to the central and eastern North Pacific Ocean may be due to colloidal Fe removal as well as particulate Fe by particle scavenging during passing from the western to eastern regions. All of these factors point toward different residence times for iron in the surface and deep waters of these regions. Therefore, the $[\mathrm{D}-\mathrm{Fe}]$ profiles are generated by a complicated balance between surface input, biological uptake, vertical flux, in situ regeneration, particle scavenging, and physical mixing.

[22] In bottom waters at B2, B3, S2, and S5 in slope region and at B1 in basin region, the sudden or gradual increase in [T-Fe] with depth (Figure 8) is probably due to the resuspension of sediments from the seafloor. Especially, the extremely high $[\mathrm{T}-\mathrm{Fe}]$ were observed in the bottom water near seafloor at B2 and S2 of the steep slope regions. The increase in $[\mathrm{T}-\mathrm{Fe}]$ with depth in bottom waters was also observed at wide area in the North Pacific Ocean [Ezoe et al., 2004; Takata et al., 2005; Kitayama et al., 2009] and at slope regions in the semiclosed Japan Sea [Fujita et al., 2010] in previous studies.

\subsection{Relationship Between Iron and Humic-Type FDOM Through the Water Column}

[23] The low level of humic F intensity in the surface mixed layer may result from the degradation of humic-type FDOM in the photic zone. It is well known that humic F intensity remarkably decreases during photoirradiation [Mopper et al., 1991, Chen and Bada, 1992]. The distributions of humic $\mathrm{F}$ intensity and $[\mathrm{D}-\mathrm{Fe}]$ were somewhat different from those of nutrients such as nitrate (Figures 3 and 4). Among stations, there are little differences in the AOU and nutrient concentrations against $\sigma_{\theta}$ (Figures 10a-10d), while relatively large differences in the humic $\mathrm{F}$ intensity and [D-Fe] of the surface mixed layer and the upper HL (Figures 10e and 10f). Therefore, the distributions of humic F intensity and [D-Fe] were more closely related to the fractional composition of sea ice melting in addition to river inputs, lateral transport and in situ biological production/decomposition.

[24] In our previous studies [Tani et al., 2003, Takata et al., 2004, 2005; Kitayama et al., 2009; Yamashita et al., 2010], strong linear correlation between [D-Fe] $(<0.22 \mu \mathrm{m}$ fraction) and humic $F$ intensity in the central North Pacific Ocean and relatively similar linear relationships between Fe(III) hydroxide solubility ([Fe(III)sol], $<0.025 \mu \mathrm{m}$ fraction) and humic F intensity in the North Pacific Ocean, Okhotsk Sea and Japan Sea suggested that humic-type FDOM may control [Fe(III)sol] as natural organic ligands complexing with $\mathrm{Fe}(\mathrm{III})$ and, therefore, may be responsible for [D-Fe] in the deep water column. In addition, commercial humic acid, soil fulvic acid, and natural organic matter in coastal waters were found to have sufficient affinity for Fe to compete with Fe(III) hydrolysis in seawater [Kuma et al., 1996; Rose and Waite, 2003; Chen et al., 2004; Gerringa et al., 2007]. In a recent study [Laglera and van den Berg, 2009], comparative measurements of the total iron complexing capacity showed that the natural humic substance can account for the entire ligand concentration in the shallow coastal and deep ocean waters tested.

[25] In the present study, [D-Fe] in the upper HL of the slope and basin regions appeared to be associated with humic $\mathrm{F}$ intensity (Figures $3-5,8$, and 10 ), while those of the shelf region did not (Figures 6 and 9). The humic F intensity values 


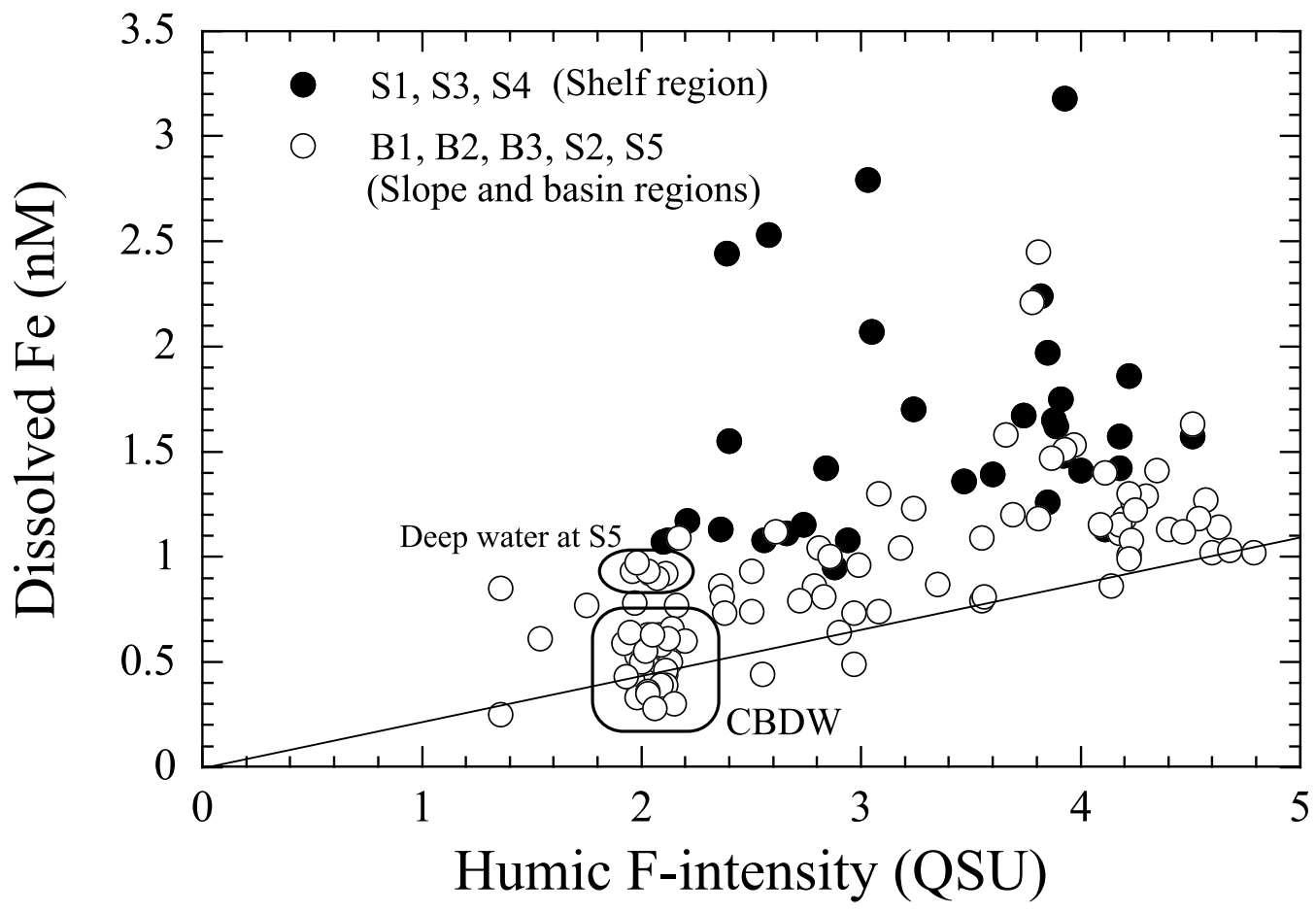

Figure 11. [D-Fe] versus humic $\mathrm{F}$ intensity at $\mathrm{B} 1, \mathrm{~B} 2, \mathrm{~B} 3, \mathrm{~S} 2$, and $\mathrm{S} 5$ of the slope and basin regions and at $\mathrm{S} 1, \mathrm{~S} 3$, and $\mathrm{S} 4$ of the shelf region. Solid line is a linear relationship between [Fe(III)sol] and humic F intensity in the central North Pacific Ocean ([Fe(III)sol $](\mathrm{nM})=0.226 \times$ humic F intensity $(\mathrm{QSU})-0.045(\mathrm{R}=$ $0.78, \mathrm{n}=14)$ ) in our previous study [Kitayama et al., 2009].

(4-5 QSU) in the upper HL of the western Arctic Ocean were approximately $1.5 \sim 2$ times higher than the maximum values (2-2.5 QSU) in the intermediate water around $1000 \mathrm{~m}$ depth in the North Pacific Ocean [Kitayama et al., 2009] and those (2-3.3 QSU) in the deep and bottom waters in the marginal Bering Sea and Japan Sea [Takata et al., 2005; Fujita et al., 2010]. Using a linear relationship between [Fe(III)sol] and humic $\mathrm{F}$ intensity in the central North Pacific Ocean (an estimated solid line: $[\mathrm{Fe}(\mathrm{III}) \mathrm{sol}](\mathrm{nM})=0.226 \times$ humic $\mathrm{F}$ intensity(QSU) $-0.045(\mathrm{R}=0.78, \mathrm{n}=14)$ in Figure 11) [Kitayama et al., 2009], we estimated whether [D-Fe] values of the shelf, slope and basin regions in the present study are attributed to [D-Fe] being nearly in solubility equilibrium with $\mathrm{Fe}$ (III) hydroxide in seawater. The [D-Fe] values $(<0.22 \mu \mathrm{m}$ size $)$ in the shelf region were generally higher than those in the slope and basin regions and were remarkably higher than [Fe(III)sol] values $(<0.025 \mu \mathrm{m}$ size $)$, which are shown as an estimated solid line of [Fe(III)sol] against humic F-intensity (Figure 11). Excess [D-Fe] than [Fe(III)sol] is probably due to the faster dissolved Fe supply rate than the removal rate and the presence of colloidal Fe form in the dissolved Fe fraction. Therefore, the higher [D-Fe] in the shelf region than the slope and basin regions may result from the rapid dissolved Fe supply from the shelf sediments and the presence of colloidal $\mathrm{Fe}$ form. The decrease in [D-Fe] from the shelf region to the slope and basin regions may be due to colloidal Fe removal as well as particulate Fe by particle scavenging during lateral transport from the shelf to the slope and basin (Figures 8 and 9). In our previous studies [Nakabayashi et al., 2001; Kuma et al., 2003; Takata et al.,
2004, 2005; Kitayama et al., 2009], the [D-Fe] at each depth in the deep water column of the western North Pacific Ocean was always higher than [Fe(III)sol] value, resulting from the higher production of dissolved $\mathrm{Fe}$ from the decomposition of sinking particulate organic matter because of the high atmospheric and/or lateral Fe inputs in the western region. However, that of the central North Pacific Ocean was almost the same as [Fe(III)sol] value, being attributed to [D-Fe] being nearly in the solubility equilibrium with $\mathrm{Fe}$ (III) hydroxide in seawater. Therefore, the [D-Fe] of the shelf water in the present study is generally oversaturated above the solubility equilibrium concentration of $\mathrm{Fe}(\mathrm{III})$ hydroxide against humic F intensity (Figure 11) and therefore may contain a large amount of colloidal $\mathrm{Fe}$ in the dissolved $\mathrm{Fe}$ fraction. However, there might be other factors inducing the high $[\mathrm{D}-\mathrm{Fe}]$ in the surface water. For example, it has been reported that $[\mathrm{D}-\mathrm{Fe}]$ and $[\mathrm{Fe}(\mathrm{III}) \mathrm{sol}]$ values in the surface water may be heightened by the high concentration or stronger affinity of natural organic Fe(III) chelators, which may be released by phytoplankton or bacteria, except for humic DOM in the present study [Kuma et al., 2000; Nakabayashi et al., 2001; Takata et al., 2004]. In deep water column (CBDW) of the slope and basin stations, except for S5, [D-Fe] levels were nearly on a solid line of [Fe(III)sol] against humic $\mathrm{F}$ intensity (Figure 11), suggesting [D-Fe] being nearly in the solubility equilibrium with $\mathrm{Fe}$ (III) hydroxide. However, the [D-Fe] levels in deep water at S5 were 2 times higher than those at other stations although the humic F intensity levels ( $\sim 2$ QSU) were almost same at all stations (Figures 5, 8, and 11), probably resulting from the 
higher biological productivity at the surface water (Figure 7a) [Nishino et al., 2008, 2009] and the higher production of dissolved $\mathrm{Fe}$ from the microbial decomposition of sinking particulate organic matter in deep water of S5 than the other slope and basin stations.

[26] In the present study, the halocline layer in the surface water of the western Arctic Ocean could be a zone of intense remineralization and thus the high concentrations of [D-Fe] and humic-type FDOM as evidenced by subsurface maxima in other nutrients and AOU. The humic-type FDOM may play an important role in regulating [D-Fe] in the water column of the western Arctic Ocean as well as other coastal and oceanic regions and in laterally transporting iron from the shelves to the Arctic Ocean interior.

[27] Acknowledgments. We thank the officers and crew of the R/V Mirai and the scientists and technicians for their help in the sampling and technical support. We are grateful to two anonymous reviewers for their constructive and helpful comments on this work. This work was supported by grants for Scientific Research Project from the Research Institute for Humanity and Nature and for Scientific Research (18201001) from the Ministry of Education, Culture, Sports, Science and Technology, Japan.

\section{References}

Aagaard, K., L. K. Coachman, and E. C. Carmack (1981), On the halocline of the Arctic Ocean, Deep Sea Res. Part I, 28, 529-545, doi:10.1016/ 0198-0149(81)90115-1.

Bergquist, B. A., and E. A. Boyle (2006), Dissolved iron in the tropical and subtropical Atlantic Ocean, Global Biogeochem. Cycles, 20, GB1015, doi:10.1029/2005GB002505.

Bergquist, B. A., J. Wu, and E. A. Boyle (2007), Variability in oceanic dissolved iron is dominated by the colloidal fraction, Geochim. Cosmochim. Acta, 71, 2960-2974, doi:10.1016/j.gca.2007.03.013.

Bruland, K. W., and E. L. Rue (2001), Analytical methods for the determination of concentrations and speciation of iron, in The Biogeochemistry of Iron in Seawater, edited by D. R. Turner and K. A. Hunter, pp. 255-289, Wiley, New York.

Bruland, K. W., K. J. Orians, and J. P. Cowen (1994), Reactive trace metals in the stratified central North Pacific, Geochim. Cosmochim. Acta, 58 3171-3182, doi:10.1016/0016-7037(94)90044-2.

Carey, E., and M. Taillefert (2005), The role of soluble Fe(III) in the cycling of iron and sulfur in coastal marine sediments, Limnol. Oceanogr., 50, 1129-1141, doi:10.4319/lo.2005.50.4.1129.

Chase, Z., K. S. Johnson, V. A. Elrod, J. N. Plant, S. E. Fitzwater, L. Pickell, and C. M. Sakamoto (2005), Manganese and iron distributions off central California influenced by upwelling and shelf width, Mar. Chem., 95 , 235-254, doi:10.1016/j.marchem.2004.09.006.

Chen, M., W.-X. Wang, and L. Guo (2004), Phase partitioning and solubility of iron in natural seawater controlled by dissolved organic matter, Global Biogeochem. Cycles, 18, GB4013, doi:10.1029/2003GB002160.

Chen, R. F., and J. L. Bada (1992), The fluorescence of dissolved organic matter in seawater, Mar. Chem., 37, 191-221, doi:10.1016/0304-4203 (92)90078-O

Coachman, L. K., K. Aagaard, and R. B. Tripp (1975), Bering Strait: The Regional Physical Oceanography, 172 pp., Univ. of Wash. Press, Seattle, Wash.

Codispoti, L. A., C. Flagg, V. Kelly, and J. H. Swift (2005), Hydrographic conditions during the 2002 SB1 process experiments, Deep Sea Res. Part II, 52, 3199-3226, doi:10.1016/j.dsr2.2005.10.007.

Croot, P. L., and K. A. Hunter (1998), Trace metal distributions across the continental shelf near Otago Peninsula, New Zealand, Mar. Chem., 62, 185-201, doi:10.1016/S0304-4203(98)00036-X.

de Baar, H. J. W., and J. T. M. de Jong (2001), Distributions, sources and sinks of iron seawater, in The Biogeochemistry of Iron in Seawater, edited by D. R. Tuner and K. A. Hunter, pp. 123-253, Wiley, New York.

Elrod, V. A., W. M. Berelson, K. H. Coale, and K. S. Johnson (2004), The flux of iron from continental shelf sediments: A missing source for global budgets, Geophys. Res. Lett., 31, L12307, doi:10.1029/2004GL020216.

Elrod, V. A., K. S. Johnson, S. E. Fitzwater, and J. N. Plant (2008), A longterm, high-resolution record of surface water iron concentrations in the upwelling-driven central California region, J. Geophys. Res., 113, C11021, doi:10.1029/2007JC004610.
Ezoe, M., T. Ishita, M. Kinugasa, X. Lai, K. Norisuye, and Y. Sohrin (2004), Distributions of dissolved and acid-dissolvable bioactive trace metals in the North Pacific Ocean, J. Oceanogr., 38, 535-550.

Fitzwater, S. T., K. S. Johnson, V. A. Elrod, J. P. Ryan, L. J. Coletii, S. J. Tanner, R. M. Gordon, and F. P. Chavez (2003), Iron, nutrient and phytoplankton biomass relationships in upwelled waters of the California coastal system, Cont. Shelf Res., 23, 1523-1544, doi:10.1016/j.csr. 2003.08.004

Fujita, S., K. Kuma, S. Ishikawa, S. Nishimura, Y. Nakayama, S. Ushizaka, Y. Isoda, S. Otosaka, and T. Aramaki (2010), Iron distributions in the water column of the Japan Basin and Yamato Basin (Japan Sea), J. Geophys. Res., 115, C12001, doi:10.1029/2010JC006123.

Gerringa, L. J. A., M. J. A. Rijkenberg, H. T. Wolterbeek, T. G. Verburg, M. Boye, and H. J. W. de Baar (2007), Kinetic study reveals weak Fe-binding ligand, which affects the solubility of $\mathrm{Fe}$ in the Scheld estuary, Mar. Chem., 103, 30-45, doi:10.1016/j.marchem.2006.06.002.

Gledhill, M., and C. M. G. van den Berg (1994), Determination of complexation of iron(III) with natural organic complexing ligands in seawater using cathodic stripping voltammetry, Mar. Chem., 47, 41-54, doi:10.1016/0304-4203(94)90012-4.

Guéguen, C., L. Guo, M. Yamamoto-Kawai, and N. Tanaka (2007), Colored dissolved organic matter dynamics across the shelf-basin interface in the western Arctic Ocean, J. Geophys. Res., 112, C05038, doi:10.1029/2006JC003584

Hansell, D. A., T. E. Whitledge, and J. J. Goering (1993), Patterns of nitrate utilization and new production over the Bering-Chukchi shelf, Cont. Shelf Res., 13, 601-627, doi:10.1016/0278-4343(93)90096-G.

Hansen, H. P. (1999), Determination of oxygen, in Methods of Seawater Analysis, edited by K. Grasshoff, K. Kremling, and M. Ehrhardt, pp. 75-89, Wiley, New York.

Hayase, K., and N. Shinozuka (1995), Vertical distribution of fluorescent organic matter along with $\mathrm{AOU}$ and nutrients in the equatorial central Pacific, Mar. Chem., 48, 283-290, doi:10.1016/0304-4203(94)00051-E. Hayase, K., H. Tsubota, I. Sunada, S. Goda, and H. Yamazaki (1988), Vertical distribution of fluorescent organic matter in the North Pacific, Mar. Chem., 25, 373-381, doi:10.1016/0304-4203(88)90117-X

Hill, V., and G. Cota (2005), Spatial patterns of primary production on the shelf, slope and basin of the western Arctic in 202, Deep Sea Res. Part II, 52, 3344-3354, doi:10.1016/j.dsr2.2005.10.001

Hutchins, D. A., G. DiTullio, and K. W. Bruland (1998), An iron mosaic in the California upwelling regime, Limnol. Oceanogr., 43, 1037-1054, doi:10.4319/lo.1998.43.6.1037

Jickells, T. D., and L. J. Spokes (2001), Atmospheric iron inputs to the oceans, in The Biogeochemistry of Iron in Seawater, edited by D. R. Tuner and K. A. Hunter, pp. 85-121, Wiley, New York.

Johnson, K. S. (2007), Developing standards for dissolved iron in seawater, Eos Trans. AGU, 88(11), 131-132, doi:10.1029/2007EO110003.

Johnson, K. S., R. M. Gordon, and K. H. Coale (1997), What controls dissolved iron concentrations in the world ocean?, Mar. Chem., 57, 137-161, doi:10.1016/S0304-4203(97)00043-1.

Johnson, K. S., F. P. Chavez, and G. E. Friederich (1999), Continentalshelf sediment as a primary source of iron for coastal phytoplankton, Nature, 398, 697-700, doi:10.1038/19511.

Johnson, K. S., F. P. Chavez, V. A. Elrod, S. E. Fitzwater, J. T. Pennington, K. R. Buck, and P. M. Waltz (2001), The annual cycle of iron and the biological response in central California waters, Geophys. Res. Lett., 28, 1247-1250, doi:10.1029/2000GL012433.

Jones, E. P., and L. G. Anderson (1986), On the origin of the chemical properties of the Arctic Ocean halocline, J. Geophys. Res., 91, 10,759-10,767, doi:10.1029/JC091iC09p10759.

Jones, E. P., L. G. Anderson, and J. H. Swift (1998), Distribution of Atlantic and Pacific waters in the upper Arctic Ocean: Implications for circulation, Geophys. Res. Lett, 25, 765-768, doi:10.1029/98GL00464.

Kaupp, L. J., C. I. Measures, K. E. Selph, and F. T. Mackenzie (2011), The distribution of dissolved $\mathrm{Fe}$ and $\mathrm{Al}$ in the upper waters of the Eastern Equatorial Pacific, Deep Sea Res. Part II, 58, 296-310.

Kitayama, S., et al. (2009), Controls on iron distributions in the deep water column of the North Pacific Ocean: Iron(III) hydroxide solubility and marine humic-type dissolved organic matter, J. Geophys. Res., 114, C08019, doi:10.1029/2008JC004754.

Kuma, K., J. Nishioka, and K. Matsunaga (1996), Controls on iron(III) hydroxide solubility in seawater: The influence of $\mathrm{pH}$ and natural organic chelators, Limnol. Oceanogr., 41, 396-407, doi:10.4319/lo.1996.41.3.0396. Kuma, K., A. Katsumoto, N. Shiga, T. Sawabe, and K. Matsunaga (2000), Variation of size-fractionated $\mathrm{Fe}$ concentrations and $\mathrm{Fe}(\mathrm{III})$ hydroxide solubilities during a spring phytoplankton bloom in Funka Bay (Japan), Mar. Chem., 71, 111-123, doi:10.1016/S0304-4203(00)00044-X.

Kuma, K., Y. Isoda, and S. Nakabayashi (2003), Control on dissolved iron concentrations in deep waters in the western North Pacific: Iron(III) 
hydroxide solubility, J. Geophys. Res., 108(C9), 3289, doi:10.1029/ 2002JC001481.

Laës, A., S. Blain, P. Laan, E. P. Achterberg, G. Sarthou, and H. J. W. de Baar (2003), Deep dissolved iron profiles in the eastern North Atlantic in relation to water masses, Geophys. Res. Lett., 30(17), 1902, doi:10.1029 2003GL017902.

Laës, A., S. Blain, P. Laan, S. J. Ussher, E. P. Achterberg, P. Treguer, and H. J. W. de Baar (2007), Sources and transport of dissolved iron and manganese along the continental margin of the Bay of Biscay, Biogeosciences, 4, 181-194, doi:10.5194/bg-4-181-2007.

Laglera, L. M., and C. M. G. van den Berg (2009), Evidence for geochemical control of iron by humic substances in seawater, Limnol. Oceanogr., 54, 610-619, doi:10.4319/1o.2009.54.2.0610.

Lam, P. J., and J. K. B. Bishop (2008), The continental margin is a key source of iron to the HNLC North Pacific Ocean, Geophys. Res. Lett. 35, L07608, doi:10.1029/2008GL033294

Lam, P. J., J. K. B. Bishop, C. C. Henning, M. A. Marcus, G. A. Waychunas, and I. Y. Fung (2006), Wintertime phytoplankton bloom in the subarctic Pacific supported by continental margin iron, Global Biogeochem. Cycles, 20, GB1006, doi:10.1029/2005GB002557.

Lohan, M. C., A. M. Aguilar-Islas, R. P. Franks, and K. W. Bruland (2005), Determination of iron and copper in the seawater at $\mathrm{pH} 1.7$ with a new commercially available chelating resin, NTA Superflow, Anal. Chim. Acta, 530, 121-129, doi:10.1016/j.aca.2004.09.005.

Luther, G. W., III, J. E. Kostka, T. M. Church, B. Sulzberger, and W. Stumm (1992), Seasonal iron cycling in the salt-marsh sedimentary environment: The importance of ligand complexes with $\mathrm{Fe}(\mathrm{II})$ and $\mathrm{Fe}$ (III) in the dissolution of Fe(III) minerals and pyrite, respectively, Mar. Chem., 40, 81-103, doi:10.1016/0304-4203(92)90049-G.

Luther, G. W., III, P. A. Shellenbarger, and P. J. Brendel (1996), Dissolved organic $\mathrm{Fe}(\mathrm{III})$ and $\mathrm{Fe}(\mathrm{II})$ complexes in salt marsh porewaters, Geochim Cosmochim. Acta, 60, 951-960, doi:10.1016/0016-7037(95)00444-0.

Macdonald, R. W., E. Sakshaug, and R. Stein (2004), The Arctic Ocean: Modern status and recent climate change, in The Organic Carbon Cycles in the Arctic Ocean, edited by R. Stein and R. S. Macdonald, pp. 6-21, Springer, New York.

Martin, J. H., R. M. Gordon, S. Fitzwater, and W. W. Broenkow (1989), VERTEX: Phytoplankton/iron studies in the Gulf of Alaska, Deep Sea Res. Part A, 36, 649-680, doi:10.1016/0198-0149(89)90144-1.

Melling, H., and E. L. Lewis (1982), Shelf drainage flows in the Beaufort Sea and their effect on the Arctic Ocean pycnocline, Deep Sea Res. Part A, 29, 967-985, doi:10.1016/0198-0149(82)90021-8.

Moore, R. M., M. G. Lowings, and F. C. Tan (1983), Geochemical profiles in the central Arctic Ocean: Their relation to freezing and shallow circulation, J. Geophys. Res., 88, 2667-2674, doi:10.1029/JC088iC04p02667.

Mopper, K., and C. A. Schultz (1993), Fluorescence as a possible tool for studying the nature and water column distribution of DOC components, Mar. Chem., 41, 229-238, doi:10.1016/0304-4203(93)90124-7.

Mopper, K., X. Zhou, R. J. Kieber, D. J. Kieber, R. J. Sikorski, and R. D. Jones (1991), Photochemical degradation of dissolved organic carbon and its impact on the oceanic carbon cycle, Nature, 353, 60-62, doi:10.1038/353060a0.

Nakabayashi, S., M. Kusakabe, K. Kuma, and I. Kudo (2001), Vertical distributions of iron(III) hydroxide solubility and dissolved iron in the northwestern North Pacific Ocean, Geophys. Res. Lett., 28, 4611-4614, doi:10.1029/2001GL013591.

Nakatsuka, T., C. Yoshikawa, M. Toda, K. Kawamura, and M. Wakatsuchi (2002), An extremely turbid intermediate water in the Sea of Okhotsk: Implication for the transport of particulate organic matter in a seasonally ice-bound sea, Geophys. Res. Lett., 29(16), 1757, doi:10.1029/ $2001 \mathrm{GL} 014029$

Nakatsuka, T., T. Fujimune, C. Yoshikawa, S. Noriki, K. Kawamura Y. Fukamachi, G. Mizuta, and M. Wakatsuchi (2004), Biogenic and lithogenic particle fluxes in the western region of the Sea of Okhotsk: Implications for lateral material transport and biological productivity, J. Geophys. Res., 109, C09S13, doi:10.1029/2003JC001908.

Nakayama, Y., K. Kuma, S. Fujita, K. Sugie, and T. Ikeda (2010), Temporal variability and bioavailability of iron and other nutrients during the spring phytoplankton bloom in the Oyashio region, Deep Sea Res. Part II, 57, 1618-1629, doi:10.1016/j.dsr2.2010.03.006.

Nédélec, F., P. J. Statham, and M. Mowlem (2007), Processes influencing dissolved iron distributions below the surface at the Atlantic OceanCeltic Sea shelf edge, Mar. Chem., 104, 156-170, doi:10.1016/j. marchem.2006.10.011.

Nevin, K. P., and D. R. Lovley (2002), Mechanisms for accessing insoluble $\mathrm{Fe}(\mathrm{III})$ oxide during dissimilatory $\mathrm{Fe}(\mathrm{III})$ reduction by Geothrix fermentans, Appl. Environ. Microbiol., 68, 2294-2299, doi:10.1128/AEM.68.5.22942299.2002.
Nishino, S., K. Shimada, M. Itoh, M. Yamamoto-Kawai, and S. Chiba (2008), East-west differences in water mass, nutrient, and chlorophyll $a$ distributions in the sea ice reduction region of the western Arctic Ocean, J. Geophys. Res., 113, C00A01, doi:10.1029/2007JC004666.

Nishino, S., K. Shimada, M. Itoh, and S. Chiba (2009), Vertical double silicate maxima in the sea-ice reduction region of the western Arctic Ocean: Implications for an enhanced biological pump due to sea-ice reduction, J. Oceanogr., 65, 871-883, doi:10.1007/s10872-009-0072-2.

Nishioka, J., S. Takeda, I. Kudo, D. Tsumune, T. Yoshimura, K. Kuma, and A. Tsuda (2003), Size-fractionated iron distributions and ironlimitation processes in the subarctic NW Pacific, Geophys. Res. Lett., 30(14), 1730, doi:10.1029/2002GL016853.

Nishioka, J., et al. (2007), Iron supply to the western subarctic Pacific: Importance of iron export from the Sea of Okhotsk, J. Geophys. Res., 112, C10012, doi:10.1029/2006JC004055.

Obata, H., H. Karatani, and E. Nakayama (1993), Automated determination of iron in seawater by chelating resin concentration and chemiluminescence detection, Anal. Chem., 65, 1524-1528, doi:10.1021/ac00059a007.

Otosaka, S., T. Tanaka, O. Togawa, H. Amano, E. V. Karasev, M. Minakawa, and S. Noriki (2008), Deep sea circulation of particulate organic carbon in the Japan Sea, J. Oceanogr., 64, 911-923, doi:10.1007/ s10872-008-0075-4

Rose, A. L., and T. D. Waite (2003), Kinetics of iron complexationby dissolved natural organic matter in coastal waters, Mar. Chem., 84, 85-103, doi:10.1016/S0304-4203(03)00113-0.

Rue, E. L., and K. W. Bruland (1995), Complexation of iron(III) by natural organic ligands in the central North Pacific as determined by new competitive ligand equilibration/adsorptive cathodic stripping voltammetric method, Mar. Chem., 50, 117-138, doi:10.1016/0304-4203(95)00031-L.

Saitoh, Y., K. Kuma, Y. Isoda, H. Kuroda, H. Matsuura, T. Wagawa, H. Takata, N. Kobayashi, S. Nagao, and T. Nakatsuka (2008), Processes influencing iron distribution in the coastal water of the Stugaru Strait, Japan, J. Oceanogr., 64, 815-830, doi:10.1007/s10872-008-0068-3.

Shimada, K., E. C. Carmack, K. Hatakeyama, and T. Takizawa (2001), Varieties of shallow temperature maximum waters in the western Canada Basin of the Arctic Ocean, Geophys. Res. Lett., 28, 3441-3444, doi:10.1029/2001GL013168.

Shimada, K., M. Itoh, S. Nishino, F. McLaughlin, E. Carmack, and A. Proshutinsky (2005), Halocline structure in the Canada Basin of the Arctic Ocean, Geophys. Res. Lett., 32, L03605, doi:10.1029/2004GL021358.

Steele, M., J. Morison, W. Ermold, I. Rigor, M. Ortmeyer, and K. Shimada (2004), Circulation of summer Pacific halocline water in the Arctic Ocean, J. Geophys. Res., 109, C02027, doi:10.1029/2003JC002009.

Sunda, W., and S. Huntsman (1995), Iron uptake and growth limitation in oceanic and coastal phytoplankton, Mar. Chem., 50, 189-206, doi:10.1016/0304-4203(95)00035-P.

Swift, J. H., E. P. Jones, K. Aagaard, E. C. Carmack, M. Hingston, R. W. Macdonald, F. A. McLaughlin, and R. G. Perkin (1997), Waters of the Makarov and Canada basins, Deep Sea Res. Part II, 44, 1503-1529, doi:10.1016/S0967-0645(97)00055-6.

Takata, H., et al. (2004), Spatial variability of iron in the surface water of the northwestern North Pacific Ocean, Mar. Chem., 86, 139-157, doi:10.1016/j.marchem.2003.12.007.

Takata, H., K. Kuma, S. Iwade, Y. Isoda, H. Kuroda, and T. Senjyu (2005), Comparative vertical distributions of iron in the Japan Sea, the Bering Sea and the western North Pacific Ocean, J. Geophys. Res., 110, C07004, doi:10.1029/2004JC002783.

Takata, H., K. Kuma, Y. Saitoh, M. Chikira, S. Saitoh, Y. Isoda, S. Takagi, and K. Sakaoka (2006), Comparing the vertical distribution of iron in the eastern and western North Pacific Ocean, Geophys. Res. Lett., 33, L02613, doi:10.1029/2005GL024538.

Takata, H., K. Kuma, Y. Isoda, S. Otosaka, T. Senjyu, and M. Minagawa (2008), Iron in the Japan Sea and its implications for the physical processes in deep water, Geophys. Res. Lett., 35, L02606, doi:10.1029/ 2007GL031794

Tani, H., J. Nishioka, K. Kuma, H. Takata, Y. Yamashita, E. Tanoue, and T. Midorikawa (2003), Iron(III) hydroxide solubility and humic-type fluorescent organic matter in the deep water column of the Okhotsk Sea and the northwestern North Pacific Ocean, Deep Sea Res. Part I, 50, 1063-1078, doi:10.1016/S0967-0637(03)00098-0.

Ussher, S. J., P. J. Worsfold, E. P. Achterberg, A. Laës, S. Blain, P. Laan, and H. J. W. de Baar (2007), Distributions and redox speciation of dissolved iron on the European continental margin, Limnol. Oceanogr. 52, 2530-2539, doi:10.4319/1o.2007.52.6.2530.

Wang, D., S. M. Henrichs, and L. Guo (2006), Distributions of nutrients, dissolved organic carbon and carbohydrates in the western Arctic Ocean, Cont. Shelf Res., 26, 1654-1667, doi:10.1016/j.csr.2006.05.001. 
Woodgate, R. A., and K. Aagaard (2005), Revising the Bering Strait freshwater flux into the Arctic Ocean, Geophys. Res. Lett., 32, L02602, doi:10.1029/2004GL021747.

Yamamoto-Kawai, M., F. A. McLaughlin, E. C. Carmack, S. Nishino, and K. Shimada (2008), Freshwater budget of the Canada Basin, Arctic Ocean, from salinity, $\delta^{18} \mathrm{O}$, and nutrients, J. Geophys. Res., 113, C01007, doi:10.1029/2006JC003858.

Yamashita, Y., R. M. Cory, J. Nishioka, K. Kuma, E. Tanoue, and R. Jaffe (2010), Fluorescence characteristics of dissolved organic matter in the deep waters of the Okhotsk Sea and the northwestern North Pacific
Ocean, Deep Sea Res. Part II, 57, 1478-1485, doi:10.1016/j.dsr2.2010. 02.016 .

S. Fujita and Y. Nakayama, Graduate School of Environmental Science, Hokkaido University, Kita 10-Nishi 5, Kita-ku, Sapporo, Hokkaido 060-0810, Japan.

K. Kuma (corresponding author), Faculty of Fisheries Sciences, Hokkaido University, 3-1-1 Minato, Hakodate, Hokkaido 041-8611, Japan. (kuma@fish.hokudai.ac.jp)

K. Shimada, Department of Ocean Sciences, Tokyo University of Marine Science and Technology, 4-5-7 Kohnan, Minato-ku, Tokyo 108-8477, Japan. 